Utah State University

DigitalCommons@USU

$5-1973$

\title{
The Validity of Awarding Credit by Examination in English Composition
}

Mark Guymon Christensen

Utah State University

Follow this and additional works at: https://digitalcommons.usu.edu/etd

Part of the Psychology Commons

\section{Recommended Citation}

Christensen, Mark Guymon, "The Validity of Awarding Credit by Examination in English Composition" (1973). All Graduate Theses and Dissertations. 5692.

https://digitalcommons.usu.edu/etd/5692

This Dissertation is brought to you for free and open access by the Graduate Studies at DigitalCommons@USU. It has been accepted for inclusion in All Graduate Theses and Dissertations by an authorized administrator of DigitalCommons@USU. For more information, please contact digitalcommons@usu.edu.

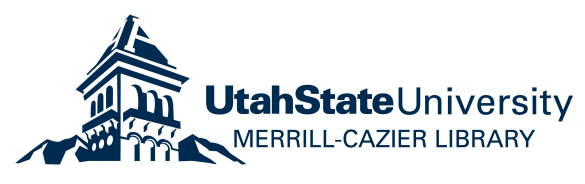


THE VALIDITY OF AWARDING CREDIT BY EXAMINATION

IN ENGLISH COMPOSITION

by

Mark Guymon Christensen

A dissertation submitted in partial fulfillment

of the requirements for the degree

of

DOCTOR OF PHILOSOPHY

in

Educational Psychology

Approved:

UTAH STATE UNIVERSITY

Logan, Utah 


\section{ACKNOWLEDGMENTS}

I wish to thank all those who assisted in the completion of this study.

To my advisor, Dr. Keith T. Checketts, I express sincere appreciation for his guidance, suggestions and encouragement before and during the writing of this dissertation.

I would like to give special mention to Dr. Rex L. Hurst and to Dr. Donald V. Sisson for their help with some of the statistical aspects of the study. To my graduate committee--Dr. David R. Stone, Dr. Elwin C. Nielsen, Dr. Ross R. Allen, and Dr. Donald V. Sisson I express appreciation for reviewing the manuscript and making suggestions for improvement.

I also acknowledge with appreciation the College of Humanities, Arts, and Social Sciences for providing the financial aid necessary to conduct the study. In addition, I would like to thank Dr. Kenneth B. Hunsaker, Prof. Ronald W. Smith, and Mrs. Jean Andra of the Utah State University English Department for grading the essay test used in the study.

Finally, I would like to thank my wife, Janet, for her encouragement and support.

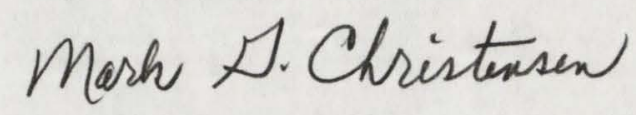

Mark G. Christensen 
Chapter

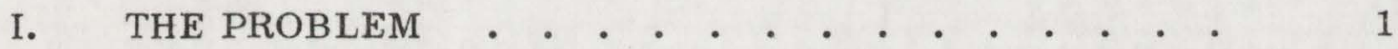

Introduction . . . . . . . . . . . . . . . 1

Purpose of the Study . . . . . . . . . . . 2

Organization . . . . . . . . . . . . . 2

Statement of the Problem . . . . . . . . . 4

Objective of the Study . . . . . . . . . . . . 44

Definition of Terms . . . . . . . . . . . 44

Procedures for the Study . . . . . . . . . . 6

Questions . . . . . . . . . . . . 9

Summary . . . . . . . . . . . . 10

II. REVIEW OF LITERATURE . . . . . . . . . . 11

Introduction . . . . . . . . . . . . . . . . 11

Essay Rating . . . . . . . . . . . . . . . 12

Objective and Essay Tests of Writing Ability . . . . .

Studies of Methods . . . . . . . . . . . 23

Related Studies . . . . . . . . . . . . . 25

Validity of Credit by Examination . . . . . . . 27

Summary . . . . . . . . . . . . 30

III. DESIGN AND METHODOLOGY . . . . . . . . . 31

Introduction . . . . . . . . . . . . . . . 31

Population and Selection of Sample . . . . . . . 31

Description of Instruments Used . . . . . . . . 35

Procedures . . . . . . . . . . . . . 40

Hypotheses to be Tested . . . . . . . . . 41 
TABLE OF CONTENTS (Continued)

Chapter

Page

IV. RESULTS . • • • • • • • • • . • • 48

The Essay Test . • . . . . . . . . . . 48

The Objective Test . . . . . . . . . . 61

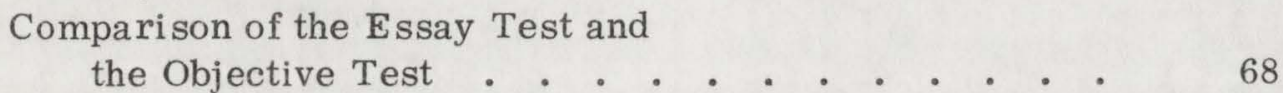

Summary . . . . . . . . . . . . 71

V. SUMMARY AND CONCLUSIONS . . . . . . . 74

Problem and Objectives . . . . . . . . . 74

Limitations of the Sample . • . . . . . . . 76

Limitations of the Instruments . . . . . . . 76

Other Limitations . . . . . . . . . . . . 77

Conclusions . . . . . . . . . . . . . . 77

Implications . . . . . . . . . . . . . 78

Recommendations for Further Research . . . . . 78

BIBLIOGRAPHY • • • • • • • • • • • • • • • 80

APPENDICES . . • . . . . . . . . . . . . . . . . . 91

Appendix A: Letter and Postcard Sent to Students . . . 92

Appendix B: The Questionnaire . . . . . . . 95

Appendix C: Directions for the Essay Test . . . . . 100

Appendix D: Multiple Regression Data . . . . . . 102

VITA . . . . . . . . . . . . . . . . . . 109 


\section{LIST OF TABLES}

Table

1. Total number in each category and number by sex

2. Analysis of variance, means, standard deviations, and differences between means for grader 1 . . .

3. Analysis of variance, means, standard deviations, and differences between means for grader 2 .

4. Analysis of variance, means, standard deviations, and differences between means for grader 3 . . . .

5. Analysis of variance, means, standard deviations, and differences between means summing scores for all three graders . . . . . . . . . .

6. Analysis of variance, mean and differences between means based on the composite essay test scores when ability is held constant . . . . . . . . . .

7. Parametric contrast of Freshman English and nonFreshman English students on the Essay Test . . . .

8. Analysis of variance, means, standard deviations and differences between means on the Objective Test

9. Significant Objective Test differences . . . . . .

10. Analysis of variance, means, standard deviations and differences between means on the Objective Test when ability is held constant . . . . . . .

11. Parametric contrast of Freshman English and nonFreshman English students on the Objective Test

12. Parametric contrast of Freshman English and nonFreshman English students on the Objective Test holding ability constant 


\section{LIST OF TABLES (Continued)}

Table

13. Percentage of variability of Freshman English grades explained by ACT scores, high school grades, and the Essay and Objective tests. (Listed in order of deletion from regression analysis.

14. Percentage of variability explained by the Essay Test and the Objective Test . . . . . . . . . 


\author{
ABSTRAC T \\ The Validity of Awarding Credit by Examination \\ in English Composition \\ by \\ Mark Guymon Christensen, Doctor of Philosophy \\ Utah State University, 1973
}

\title{
Major Professor: Dr. Keith T. Checketts
}

Department: Psychology

This study investigated the validity of excusing students from composition courses based upon an objective examination.

Utah State University (USU) students who had taken freshman composition courses during the 1970-71 school year when these courses were required of all entering freshman students were divided into two groups: one group was composed of those who had received an "A" or "B" for three freshman composition courses, while the other group had received a " $C$ " or " $D$ " for the same courses. USU students who had been excused from taking freshman composition courses based on the CLEP General Examination in English Composition (CLEP) during the 1971-72 school year when all entering freshman students were required to take the CLEP were divided into two groups: one group had scored above 449 on the CLEP and the other group had scored from 390-449. In addition, students who had been excused from the same composition require- 
ment based on a score above 2 on the Advanced Placement Test in English Composition (AP) were included in the study. A random sample of 25 from each of the above groups participated in the study.

All subjects completed an essay test (CLEP Subject Examination in English Composition--Essay Section) and an objective test (CLEP Subject Examination--Objective Section). The essay test was rated independently by three members of the USU English Department, and an inter-rater reliability coefficient of . 83 was obtained using analysis of variance techniques.

Results showed that on the bases of both the essay test and the objective test there was no significant difference in the writing ability of the two groups of students who had completed freshman composition courses and the two groups of students who had been excused from freshman composition courses based on the CLEP. On the bases of both of these tests, the students who scored above 2 on the AP test scored above all other groups in the study; the students who scored above 449 on the CLEP scored second to the AP students and very much like the students who had received an average of "A" or "B" in freshman composition courses; the students who scored 390-449 and those who received a "C" or "D" in composition courses received virtually identical scores on the essay and objective tests.

Based on multiple regression analysis, the objective test was found to be a much better predictor of freshman English grades than the essay test. In addition, the essay test was found to add little to the prediction of freshman composition grades provided by the objective test alone. 
Based on the findings of the study, it was concluded that the CLEP had been accurately applied at USU. Based upon the assumption that freshman composition grades are a valid measure of writing ability, it was also concluded that the objective test used in the study was a more valid measure of writing ability than the essay test, and further concluded that the objective test could predict writing ability quite accurately independent of the essay test.

In consideration of the previous conclusions, it was concluded that a strictly objective test can validly be used to excuse students from freshman composition courses.

(118 pages) 


\section{CHAPTER I}

\section{THE PROBLEM}

\section{Introduction}

Development of the ability to write has been considered of such importance in the American school system that traditionally, writing instruction begins with the student's first year in school and continues into the collegiate experience.

While the importance of acquiring the ability to write seems to be universally accepted, there is considerable disagreement concerning what constitutes a reliable and valid assessment of writing ability.

Although a single assessment of writing ability from a writing sample was traditionally regarded as reliable and valid, as early as 1888 Edgeworth "unearthed evidence documenting the unsatisfactory nature of the methods adopted in assessing essay or composition ability." (Anderson, 1960, p. 95)

Since 1888 , many studies have been conducted which have attempted to find ways of assessing writing samples reliably. Braddock et al. (1963) have reviewed 502 English composition studies conducted since 1902 many of which deal with or provide evidence of problems of low reliability. More recent literature discusses similar types of problems (McColly, 1970).

While attempts to reliably assess a writing sample have rarely proved successful, since the 1930 's objective assessments of writing ability have been 
found to be more reliable and valid than subjective assessments (Huddleston, 1954; Pidgeon and Yates, 1957; Cowles and Hubbard, 1952; Stalnaker, 1933). Nevertheless, some have tenaciously held to the belief that for assessments of writing ability to be valid they must be based to some extent, at least, upon a writing sample.

\section{Purpose of the Study}

Although differences of opinion concerning the validity of certain methods of assessing English composition ability still exist, the use of strictly objective tests as the basis for awarding credit for composition has recently come into wide use. Yet, an examination of recent literature suggests that little, if any, research has been conducted which has directly tested the validity of using either an objective test or an essay test as the basis for excusing students from freshman English. The purpose of this study is to more directly assess the validity of the use of essay and objective methods to excuse students from freshman English.

\section{Organization}

The first chapter of this study is an introduction to the study and includes an overview of the problem, a statement of the problem, a definition of terms, an outline of the procedures used to collect data for the study, and a listing of the questions the study will attempt to answer. 
In providing a framework for the present study, the second chapter discusses literature pertaining to the assessment of writing ability from an essay test. Studies comparing essay and objective tests of writing ability are then discussed. This discussion is followed by a review of data from studies which compared the improvement in writing ability of students who were taught composition in different ways. Data from studies similar to the present study in which students who have taken freshman English are compared to students who have not taken freshman English are then presented. Finally, studies of the validity of credit by examination, in general, and then, specifically, studies of the validity of the CLEP General Examination in English Composition are discussed.

Although the review of literature does not attempt to discuss exhaustively the topics presented, it does attempt to provide a background of recent and significant research conducted in the areas considered. No attempt was made to discuss areas of composition which did not seem relevant to the present study such as the role of environmental factors on composition, etc.

The procedures, sample, and instruments used in the study are discussed in Chapter III. In addition, a discussion of the questions and hypotheses of the study is given.

Chapter IV presents the data pertaining to the hypotheses of the study, while Chapter $\mathrm{V}$ discusses the findings and summarizes the study. 


\section{Statement of the Problem}

The problem is to determine whether students can validly be excused from, or can validly receive credit for meeting a college composition requirement by means of an objective test.

\section{Objective of the Study}

A main objective of this study was to more directly assess the validity of the practice of granting college composition crecit by strictly objective examination.

\section{Definition of Terms}

Some of the terms and abbreviations used in this study are defined below.

CEEB. -- This abbreviation refers to the College Entrance Examination Board which developed the College-Level Examination Program. The College Entrance Examination Board was organized in 1900 "... to provide a channel of communication between the schools and colleges and to encourage a degree of informity in the secondy school curriculum (Angoff and Dyer, 1971, p. 1)". Although, "... examinations were secondary to the main purpose of the Board ...", the Board is probably best known by its examinations.

CLEP. -- This abbreviation is used to denote the College-Level Examination Program. 


\section{Essay Test. -- The term "Essay Test" refers to the essay part of the}

CLEP Subject Examination in English Composition which was given to the subjects in the study. The Essay Test is described in Chapter III.

Freshman English.-- When "Freshman English" is capitalized it refers to English 101, 102 and 103 taught at Utah State University. A description of Freshman English will be presented in Chapter III of this study.

Freshman English Requirement.-- During the 1970-71 Utah State University school year and for many years prior to that time, the completion of English 101, 102, 103 or scoring 3, 4, or 5 on the Advanced Placement Test in English Composition was a graduation requirement.

Beginning with the Fall Quarter, 1971, the Freshman English Requirement was changed so that it could also be met by students who scored above 389 on the CLEP General Examination in English Composition which all Utah State University freshman students were required to take in the fall of 1971. Students who scored from 390-449 on the CLEP General Examination in English Composition met the Freshman English Requirement, but did not receive English credit. Students who scored above 449 met the Freshman English Requirement, and received English credit.

Objective Test. -- The term "Objective Test" refers to the objective part of the CLEP Subject Examination in English Composition. The Objective Test is described in Chapter III. 
Reliability.-- "As used in psychometrics, the term reliability always means consistency.... Reliability can be checked with reference to temporal fluctuations, the particular selection of items or behavior sample constituting the test, the role of examiners or scorers, and other aspects of the testing situation" (Anastasi, 1969, p. 29).

Reliability has an important connection to validity. Reliability is "... a necessary but not sufficient condition for any type of validity." (Nunnally, 1967, p. 217). The upper limit of validity is the square root of reliability. Validity. -- "Undoubtedly the most important question to be asked about any psychological test concerns its validity, i.e., the degree to which the test actually measures what it purports to measure.... The determination of validity usually requires independent, external criteria of whatever the test is designed to measure. For example, if a medical aptitude test is to be used in selecting promising applicants for medical school, ultimate success in medical school would be a criterion" (Anastasi, 1969, p. 28).

\section{Procedures for the Study}

With the need for data concerning whether students can validly be excused from meeting a college composition requirement, the basic design of the present study was to compare the writing ability of students who had met a composition requirement by completing composition courses with the writing abilities of students who had met a composition requirement by examination. 
During the 1970-71 school year and for many years prior to that year, all freshman students at Utah State University who had not received Advanced Placement credit in English Composition were required to take Freshan English. The following year (1971-72), all Utah State University freshmen students who had not received Advanced Placement credit in English Composition were required to take the CLEP General Examination in English Composition.

In attempting to determine whether students can validly be excused from meeting a composition requirement based on either an essay test, or an objective test, the writing abilities of groups of students who had completed Freshman English during the 1970-71 school year were compared with the writing abilities of students who were excused from Freshman English during the 1971-72 school year. In addition, a group of students who received Advanced Placement credit in English Composition during the 1971-72 school year participated in the study.

Using a table of random numbers, a sample of 25 students was selected from each of the following categories:

1. Freshman English (A-B)

1970-71 Utah State University freshman students who received a Freshman English grade-point average of "A" or "B".

2. Freshman English (C-D)

1970-71 Utah State University freshman students who received a Freshman English grade-point average of "C" or "D". 


\section{CLEP Credit}

1971-72 Utah State University freshman students who scored above 449 on the CLEP General Examination in English Composition.

\section{CLEP Waiver}

1971-72 Utah State University freshman students who scored 390449 on the CLEP General Examination in English Composition.

\section{Advanced Placement}

1971-72 Utah State University freshman students who had received Advanced Placement credit in English Composition.

In selecting the categories for the study, it was assumed that the CLEP credit students and the Freshman English (A-B) students were from the same population in terms of writing ability since they have been treated similarly with regard to the Freshman English Requirement. Likewise, it was assumed that the CLEP Waiver and Freshman English (C-D) students were from the same population in terms of writing ability.

The ability of the CLEP Credit and Freshman English (A-B) students was assumed to be above the abilities of the CLEP Waiver and Freshman English (C-D) students. The Advanced Placement students were assumed to have very high ability.

Because data was needed concerning the validity of excusing students from composition courses based on either an essay or an objective test, all students in the study were given both an essay and an objective test. The 
essay test was scored by three members of the Utah State University English department, while the objective test was machine scored.

\section{Questions}

In consideration of the problem and design of the study the following questions were framed:

1. Can essay raters rate reliably?

2. Is there a difference in the Essay Test scores of the five groups who have met a Freshman English Requirement in one of the following ways: (1) scoring 3,4 , or 5 on the Advanced Placement Test in English Composition; (2) scoring 390-449 on the CLEP General Examination in English Composition; (3) scoring 450 or above on the CLEP General Examination in English Composition; (4) taking Freshman English and receiving a Freshman English grade-point average of $2.7-4.0$; (5) taking Freshman English and receiving a Freshman English grade-point average of $1.0-2.3 ?$

3. When ability is held constant, is there a difference in the Essay Test scores of the five groups?

4. Is there a difference in the Essay Test scores of students who have taken Freshman English and students who have not taken Freshman English?

5. When ability is held constant, is there a difference in the Essay 
Test scores of students who have taken Freshman English, and students who have not taken Freshman English?

6. Is there a difference in the Objective Test scores of the five groups?

7. When ability is held constant, is there a difference in the Objective Test scores of the five groups?

8. Is there a difference in the Objective Test scores of the students who have taken Freshman English and the students who have not taken Freshman English?

9. When ability is held constant, is there a difference in the Objective Test scores of the students who have taken Freshman English and the students who have not taken Freshman English?

10. Is there a difference in the proportion of the variability of Freshman English grades that the Essay Test and the Objective Test explain?

\section{Summary}

In introducing the study, this chapter has suggested that there is a need for a more direct assessment of the validity of the widely used practice of excusing students from composition courses based on a strictly objective assessment of their writing ability.

Some of the terms and abbreviations used in the study were defined. The procedures this study used as well as the questions this study has attempted to answer were also presented. 
CHAPTER II

REVIEW OF LITERATURE

\section{Introduction}

While evaluation has always been an essential part of the educational process, evaluation of the ability to write has posed a unique evaluation problem. Reporting implications of National Assessment writing results, Farrell (1971), Assistant Executive Secretary National Council of Teachers of English, indicated that problems of assessment continue to be one of the perplexing areas of English.

Palmer (1960, p. 8) emphasized the complexity that the writing assessment problem has been to the College Entrance Examination Board when he stated: "The task of the College Board of English Examiners, beyond any question, has been the most complex, most vexing, and most baffling that any College Board test committee has had to face. Certainly no committee has spent more time in sober appraisal and painful reappraisal of its work, and no [other] College Board examination across the years has undergone so many alterations and refinements.

A brief history of some of the "alterations and refinements" of the College Board's English tests can be found in French, 1961; Fremer and Chandler, 1971; and Palmer, 1960. 
While teachers have always been concerned about time spent in grading papers, relatively recently they have shown more concern with evaluation. Logan (1970, p. 548) stated that, "If the number of articles that deal with composition evaluation published in professional journals within the last five years is an indication of concern about composition evaluation, English teachers are concerned."

Denby (1968, p. 1215), a staff writer for the English Journal, expressed about the same opinion as Logan when he stated that, "composition evaluation remains an important concern of teachers of English in colleges and secondary schools. One indication of this is that eighteen English Journal articles have been devoted solely or in large part to the topic in the last five years."

\section{$\underline{\text { Essay Rating }}$}

While evaluation remains a problem, several researchers have attempted to summarize what is known about the evaluation of a writing sample (Braddock, 1969; Braddock, et al., 1963; Coffman, 1969; French, 1961; Finlayson, 1951; and McColly, 1970). A discussion will be given of some of the aspects of rating writing samples suggested by these writers and others. Relevant research, when available, will be discussed.

In behalf of the National Council of Teachers of English, Braddock et al., (1963) reviewed 504 studies of research conducted in written composition. Based upon their review of research and experience in this a rea of composition rating, 
Braddock et al. (1963) classified the variables having to do with the judging of writing ability into four areas of variability. The first is the "writer variable," which refers to the students' variability in writing quality on different days. The second is the "assignment variable" which includes writing va riability due to differences in the "... topic, the mode of discourse, the time afforded for writing, and the examination situation." (p. 7). The third area is the "... rater-variable--the tendency of a rater to vary his own standards of evaluation." Included in this area are the "personal feelings" of the rater and "rater fatigue." The fourth area is the "... college variable--the tendency of several raters to vary from each other in their evaluations."

Research relating to these and other topics will be discussed.

The writer variable

French (1961) states that although essay and objective tests contain variations in the quality of students test performance from one day to the next, this "student error" variability is greatly increased when the student does not write according to the criteria the examiner is using as the basis of judgment. Kincaid (1953) found significant differences in the quality of student writing on a day-to-day basis.

The topic

Of the categories discussed by Braddock et al. (1963) in the area of the "assignment variable" the topic was the only category in which specific research 
was found. Several researchers have shown that an individual's essay score is significantly related to the essay topic (Finlayson, 1951; Godshalk et al., 1966; Kincaid, 1953; Newberry, 1967; and Wisemen and Wrigley, 1958). Coffman (1969, p. 11) explained the situation in this way:

There has been a tendency to emphasize the problem of reading reliability to the exclusion of other aspects of reliability. The major limitation of the essay examination is not that it is difficult to grade reliably but rather that in comparison to short answer or choice-type tests it permits only a limited sample of the student's achievement to be collected... . Since reading is much more rapid than writing, more material can be covered in an objective than an essay examination and since students differ in their ability to answer different questions, the reliability of a test is a function of the number of questions rather than the time involved. An inadequate sample, even if it is read with high reliability, cannot provide a reliable score.

Greene and Petty (1963, p. 517) make similar suggestions when they state that,

Reliable evaluation of the written products of an individual can be obtained only by (1) securing an extensive series of samples of his written expression; and (2) securing repeated ratings of the samples by an expert judge; or (3) securing many independent ratings by expert judges; or (4) by a combination of all three steps.

Kincaid (1953) found no significant difference in group's mean scores from one topic to another when he compared the same group on different topics. 
$\underline{\text { Rater fatigue }}$

After examining the data from a five-day rating session conducted at Educational Testing Service, Myers et al. (1966) showed that inter-rater reliability was significantly lower on the fifth day of the five-day session than it was on the previous four days. Coffman and Kurfman (1968) also found that fatigue was a significant factor in obtaining reliable ratings.

\section{$\underline{\text { Rater disagreement }}$}

Differences of opinion concerning what constitutes good writing as reflected by low reliability has been so typical in research studies of composition rating that Braddock $(1969, \mathrm{p} .455)$ stated, "It is common knowledge that the grading of compositions is notoriously unreliable." A few of the studies in which grading reliability, in general, has been investigated include: Fostvedt, 1965; French, 1961; Smith, 1970; and Storey, 1968.

In an extensive study in which 53 graders from six different disciplines each graded 300 papers, Diederich, French, and Carlton (French, 1961) found that the inter-rater reliability was .31 .

\section{Common criteria}

Studies have generally indicated that to use common criteria increases grading reliability. 
However, the use of common criteria alone is not sufficient to produce acceptable reliability (Fostvedt, 1965).

High reliability by multi-marking

Coffman $(1969$, p. 11) states that "since a major portion of the error variance is contributed by differences in the ordering of papers by different readers, a high reliability of reading almost always involves the summing of ratings of a number of different readers." Coffman's conclusion is confirmed by the findings of several researchers (Britton, et al. 1966; Godshalk et al., 1966; Kincaid, 1953; Lindell, 1971; and Veal et al., 1971). Pilliner (1969) investigated the validity of the use of multiple raters as advocated by Wiseman (1949). Pilliner states that Cox (1968) "... criticized the use of several markers... on the ground that the reliability may be increased at the expense of meaning" (p. 313). Pilliner presented a mathematical discussion of the Wisemen and Cox viewpoints and concluded: (p. 315)

There is some substance to this criticism [by Cox] if each marker is highly self-consistent and if at the same time each agrees poorly with every other.... If, on the other hand there is a fair measure of agreement among individual markers about the scripts' merits, the aggregated marks from a team of markers will be a valid expression of the team's consensus of opinion, the reliability of which will increase as the size of the team increases. 
Neatness and composition errors

Marshall and Powers (1969) have given evidence that essay grades are significantly affected by the neatness of the handwriting, as well as spelling and grammatical errors, when raters are significantly instructed to grade on content alone. Similar results were obtained in a related study (Scannell and Marshall, 1966).

\section{Length of scale}

While little research was found which directly compared the reliability obt ained when various scale lengths were used, Godshalk et al. (1966) found that a 4-point rating scale was superior to a 3-point scale. McColly (1965) found no statistically significant difference in the reliability obtained when using either a 4-point or 6-point scale. Jewell et al. (1969) stated a preference for a 9-point scale over a 4-point scale but gave no justification for their preference.

\section{Holistic vs. analytical reading} judgments

Coffman and Kurfman (1968) directly compared the reliabilities they obtained when they used holistic or global judgments of writing ability and analytical judgments. The researchers found no significant difference in the reliabilities obtained using either approach. Other studies have indicated that reliable ratings can be obtained when either holistic (Finlayson, 1951; 
Godshalk et al., 1966) or analytical (Stalnaker and Stalnaker, 1934; Buxton, 1958) reading judgments are made.

\section{Summary of rating compositions}

An examination of the literature pertaining to the assessment of writing ability has shown some of the difficulties involved. McColly (1970, p. 155) stated that "... to measure writing ability properly [from a writing sample] is expensive, complicated, and difficult." Coffman (1969, p. 10) echoed some of the same feelings when he stated that "in most cases ... reliable reading is achieved only at considerable cost in time and effort" (Swineford, 1956; Finlayson, 1951).

\section{Objective and Essay Tests of Writing Ability}

Comparison of essay and

objective tests

While the reliability of objective tests of writing ability is generally accepted, critics of such tests have repeatedly questioned their validity. Braddock et al. (1963, p. 42) expressed the opinions of many critics of objective tests when they stated: "The most serious charge against multiple-choice tests is their lack of validity. Not only do they not require the examinee to perform the actual behavior being measured--he does no actual writing, but 
these tests also make little or no attempt to measure the 'larger elements' of composition, even indirectly."

Although this charge continues to be made, several investigators who have investigated the unique contributions of essay and objective tests have concluded that they measure essentially the same things (Bracht and Hopkins, 1970; Godshalk et al., 1966; Modu, 1972; Pattersen, 1926; Pidgeon and Yates, 1957; Vernon, 1962; and Weidman, 1933).

Bracht and Hopkins $(1970$, p. 363) who investigated "... the extent to which essay and objective tests measure the same or different abilities when instruction or content are held constant" reached the following conclusion:

Many of the current convictions about the relative strengths and weaknesses of essay and objective tests seem to be based on impressionistic observations, not on empirical research findings. The findings of this study, together with the results yielded by an extensive literature search (Bracht and Hopkins, 1968), revealed that, with few exceptions, the evidence does not support the common assumption that essay and objective tests measure different variables, after allowance is made for errors of measurement (Cowles, and Hubbard, 1952; Horn, 1966; Patterson, 1926; Stake and Sjogren, 1964; Thompson, 1965; Vernon, 1962; Widemann and Newens, 1933).

This same question concerning the relationship between essay and objective measures of writing ability was investigated in an extensive study conducted by Godshalk, Swineford and Coffman (1966). In this study, five samples of writing for which students were permitted to write a total of two hours and 20 minutes were obtained from each of 646 students. Each sample was scored independently by five readers, and therefore, the total score for 
each individual was the summation of the scores obtained from 25 independent readings. The inter-rater reliability obtained was .92 . The score reliability (reliability of an individual's score from topic to topic) was . 84 .

Having established a reliable and valid criterion of writing ability, the scores these same 646 individuals obtained from objective tests were correlated with the criterion. Combinations of three objective tests (a one-hour test) were correlated with the criterion measure. Correlation coefficients of from .717 to .748 were obtained when twelve combinations of three objective tests were correlated with the criterion measure. The score from a 20-minute essay, when added to the one-hour objective score did increase the correlation with the criterion from . 023 to .036 to .042 depending on whether the essay had been read two, three, or four times. Godshalk et al. $(1966$, p. 41) stated that "the addition to prediction is real but small."

In reference to the above data, Edward S. Noyes, a CEEB vice-president, stated: (1963, p. 10) "... it seems impossible to justify any longer the criticism that the ECT [English Composition Test]--whether it consists of objective items only or includes an interlinear exercise is not a sound measure of the ability to write." Several years prior to this time, Noyes $(1949$, p. 120) had questioned the validity of objective attempts to measure writing ability, which he had stated (p. 120) "... can only be discovered by giving the student a blank page and a pencil and setting him to write." Pidgeon and Yates (1957, p. 47) reached about the same conclusion others have reached regarding the differences between essay and objective tests when they stated: "... the difference between 
the content of such examinations [essay tests] and those of objective tests is by no means so large as has been supposed. The difference is one of format ..."

An explanation of the evidence that essay and objective tests measure essentially the same things was given by Noyes $(1961$, p. 37) when he stated: "English is a combination of skills and knowledge, so intricately intertwined that a direct measure of one is likely to afford an indirect measure of another." While the evidence suggests that well-designed essay and objective tests measure essentially the same things, research evidence has typically favored "... well-constructed objective tests whether the criterion was judging of writing skill (Huddleston, 1954) or substantive knowledge (Cowles and Hubbard, 1952)"(Coffman, 1969, p. 11).

Based upon the data from a study in which 1500 freshman students wrote "several short samples of writing" and took an objective test Stalnaker (1933, p. 222) concluded:

In the case of marked differences between the essay and objective ratings of a student in English composition the objective rating is probably the more valid estimate. Students who receive high essay scores and low objective scores tend to be an inferior group as judged on the basis of their performance in English composition.

On the other hand, the students who receive high objective scores and low essay scores tend to be a superior group as judged on the basis of either of these two criteria.

Palmer (1961, p. 318$)$ stated that "... objective English test scores correlate higher with such criteria as course grades in English and teachers' 
rating of student writing ability than do essay test scores." Other researchers have reached similar conclusions (Knickerbocker, 1951; Pidgeon and Yates, 1957). Pidgeon and Yates (1957, p. 47) stated:

The results of the experiments that we have outlined, ... show that even in ideal conditions, which cannot in practice be contrived--that is, with a faultless system of marking-papers of this kind [essay] do not achieve the level of reliability that is maintained by objective tests, nor do they achieve the same degree of validity.

It would appear, therefore, that authorities are confronted with the difficult choice between adequate instruments that seem to have unfortunate bachwash effects and less reliable and valid forms of assessment that may conceivably-although there is no firm evidence on this point--exert a more desirable influence on the education of primary schools.

\section{$\underline{\text { Motivation }}$}

While some have contended that essay tests are needed to motivate students and teachers, the data from two studies conducted by French (1956, 1957) suggest that there is serious reason to doubt this supposition. French (1957) found that while high school teachers strongly favored the use of an essay test by the College Board in its college entrance examination testing program, "... essay tests have less effect on the amount of writing practice than do the factors of enrollment, competing activities, and even administrative pressure" (p. 201).

In the second study conducted by French (1956) concerning student preparation and motivation for essay and objective tests, Fremer and Chandler 
(1970, p. 164) reported:

At the outset, both essay and objective tests were given to four groups of students. Two groups were told that their final examination would be of the essay type and two were told that it would be of the objective type. Actually, both types were given to all groups. After the second testing, only a few students [14 percent] said that they had done anything special to prepare themselves for the expected type of test. The 'after' scores on a particular test type were not much different for students expecting that type of test than for those not expecting it; further, there was no real advantage on the 'after' test for students who said that they had prepared for that particular type of test.

\section{$\underline{\text { Studies of Methods }}$}

Although studies of methods are not directly related to the current problem, because such studies are prevalent in the literature dealing with the evaluation of English composition, some discussion will be given of the nature and findings of such studies. The studies in this section were areas in which both the experimental and control groups received some type of English instruction.

A great number of studies have been conducted comparing the effectiveness of various methods of writing instruction on the improvement of the writing ability of college freshmen. Some of those conducted in the last few years include (Becker, 1972; Buggs, 1969; Burman and Flaherty, 1968; Cohen, 1971a; Newcomb, 1970; Sears, 1970; Underwood, 1969; Wahlberg, 1970). While 
significant differences between methods are rare, researchers have occasionally reported such findings (Buxton, 1958; Lokke and Wykoff, 1948).

In regard to the methods studies which have compared writing frequency, Braddock 1969, p. 454) states that "it seems quite evident that mere frequency of writing, without motivation to write well or careful instruction in how to write well, produces no measurable results over a period as short as a semester."

Diederich (1966) indicated that the reason few significant differences were found in experiments comparing writing improvement using essay tests to measure writing achievement was due, generally, to the unreliability of grading.

Recognizing that traditional methods of teaching writing (particularly the marking of papers) demonstrated limited effectiveness in changing students writing behaviors, several educators in recent articles have suggested new approaches to marking papers (Cohen, 1971b; Hipple, 1972; Monsen, 1971; Nelson, 1967; Vogler, 1971).

Two studies in which methods were compared using sections of remedial freshman college English students also showed non-significant results (Schneider, 1970; Fadule, 1969). However, significant differences were found in a study with "retarded" college students (Maize, 1954).

Some studies comparing methods in secondary and elementary schools have also given non-significant results (Buxton, 1963; Heys, 1962; Hillerich, 1971). 


\section{Related Studies}

Several studies were found which compared the writing improvement of college students who enrolled in and completed college English courses with those who did not (Beck, 1968; Braddock and Statler, 1968; DiRusso, 1971; Jewell et al., 1966, 1969, 1970).

Jewell, et al. (1969) conducted a study to determine if significant gains in writing ability could be uniquely attributed to freshman composition instruction. Entering freshman students from five state universities were given the Cooperative English Tests--English Expression (COOP), The College Entrance Examination Board English Composition Test (CEEB), and a Theme. Based on their scores on these three measures, students were matched. One of each matched pair was randomly assigned to freshman English (experimental group), while the other was not permitted to enroll in freshman English (control group). At the end of the first, second, and fourth semesters of school students again took the three tests. The results showed that there was a significant difference in favor of the experimental group on the basis of the COOP and the Theme at the end of the first semester. At the end of the second semester, the experimental performed significantly better than the control group on the COOP only. No significant differences were found between the experimental and control groups on any of the measures at the end of the fourth semester. Throughout the study, women were found to be consistently better than men. 
Kitzhaber (1963) reported a study comparing the writing of freshman, sophomore and senior men at Dartmouth College. He found that "... sophomores made almost as many errors in their writing after a year and a half of college as freshmen do at the beginning of English 1 and more than freshmen make at the end of English 1. Seniors are worse than sophomores, having made more errors in their papers than freshmen do at the beginning of English 1." (p. 109) The sophomore and senior students in the study had completed both of the required freshman English courses at Dartmouth, or had been exempted from one or both courses.

Similar studies which also found few, if any, instances of significance between groups who had or had not completed freshman English were reported by Jewell, et al., 1970; Jewell, et al., 1966; Beck, 1968. Two studies conducted with remedial students also showed no significant differences between groups (DiRusso, 1971; Loak, 1971).

Several of the studies reported that women consistently performed better than men on tests of writing ability (Beck, 1968; Jewell et al., 1969, 1966). In reviewing studies of freshman writing, Braddock (1969, p. 45) stated that "... several of these studies were agreed that poor freshman writers tend to be male..."

Coffman (1961, p. 117) stated: "It is well known that women tend to make higher scores than men on tests of verbal aptitude." 


\section{Validity of Credit by Examination}

With the expansion of the College-Level Examination Program in the 1960 's, there has been considerable development of credit by examination programs in institutions of higher learning. However, credit by examination has been a part of the American system of higher education since as early as 1895 (Fletcher, 1932).

Various programs date from 1895 into the 1960 's (Dole, 1951; Fletcher, 1932; Garrett, 1946; Haak, 1953; Jones and Ortner, 1954a, b; Off campus studies (Times) ..., 1963; Pressey, 1949; Schuler, 1965). Attempts at estimating validities of the various programs of credit by examination, prior to the CLEP program, have generally lacked precision. The studies have compared students who received a certain amount of credit by examination with students of similar academic and socio-economic backgrounds who received less credit, or who did not take the examinations. Generally, credit by examination students have had superior grade-point averages, and a higher percentage have graduated from college (Dole, 1951; Jones and Ortner, 1954a, b; Pressey, 1945; Schuler, 1965).

Flaugher et al. (1967, p. 119) in reading Pressey's (1949) review of studies of educational acceleration conducted at Harvard (1913), Columbia (1915), University of Minnesota (1910, 1911), Dartmouth (1923), Northwestern University (1929), Columbia and Barnard (1921-25), College of the City of New York (1930), and Pennsylvania Colleges (1933), stated: "... younger entrants to these institutions were more likely to graduate, had the best academic records, won more honors, and presented fewer disciplinary difficulties." 
A study of several hundred Harvard men who entered as sophomores through examination, revealed that half of those who graduated received their degrees magna cum laude or summa cum laude (Schuler, 1965).

\section{$\underline{\text { CLEP validity }}$}

Sharon $(1970,1971 \mathrm{a}, 1971 \mathrm{~b})$ who has summarized a number of unpublished studies concerning the validity of the CLEP General Examinations, stated that "none of the studies which employed a 'before-after' design to study score gains on the GEs [General Examinations] employed a control group." (1971, p. 480) In regard to the construct validity of the tests, Sharon (1971b) reported studies by Harris and Booth (1969), French (1965) and Kolby (1969). Harris and Booth, and French reported that students showed pre- and post-test gains on the various tests while in college. Kolby tested 82 students before and after they had completed courses relevant to the examinations. The students made significant gains on the English Composition and Natural Sciences Tests.

This is in contrast to the data from the sophomore norming sample of the CLEP General Examination in English Composition. Haven (1967, p. 7) stated that "On all but the English examination, students performed best on the tests in the same general areas in which they took the most college courses. Students with the most college courses in English performed below average not only on English but also on all other tests." 
The scores of 44,000 men tested while in the service (CEEB, 1968) showed that test scores tend to increase with the amount of formal education. The analysis of these scores also tend to indicate that the tests are no harder for older than younger subjects.

The scores of about 2500 second-term college students who were the national freshman norming sample (Haven, 1967) indicate that test scores on the five general examinations correlate positively with relevant high school course experiences.

Data from the approximately 2600 college sophomores who were the sophomore norming sample (Haven, 1964), show that the highest mean scores on the five tests were obtained by sophomores intending to major in the area corresponding to the test.

The studies involving credit by examination in English composition are especially relevant to the current study. Golsby (197) reported that the CLEP General Examination in English Composition correlated . 45 with sophomore cumulative grade-point average.

Sharon (1970) reported that six universities conducted studies in which the CLEP General Examinations were correlated with overall grade-point average. "Invariably the English Composition Test was found to be the most valid one [it correlated highest with overall grade-point average], with a median coefficient of .46." (p. 344)

Sharon (1970) reported two studies showing the relationship between the CLEP General Examination in English Composition and other tests. The CLEP 
English Composition test was found to correlate . 61 with the verbal part of the Scholastic Aptitude test (Schnitzen, 1969), and to correlate .65 with the College Board's English Composition Test (Warren and Sylvan, 1969).

Both Sharon (1970, 1971a) and Findley, (1972) suggested that CLEP tests have a certain insured content validity due to the College Board's committee system of building tests described by Educational Testing Service (1965).

\section{Summary}

The literature has suggested that assessment of writing ability from a writing sample is at best inconclusive because of day-to-day variations in student writing, differences in criteria of raters, and other factors. The literature has also suggested that, generally speaking, objective tests are better measures of writing ability than essay tests.

While it appears, from the literature, that the value of college composition courses in improving students' writing ability is uncertain, studies involving the CLEP General Examination in English Composition suggest that it has some validity. However, a more direct assessment of its validity is needed. The current study will attempt to make such an assessment. 


\section{CHAPTER III \\ DESIGN AND METHODOLOGY}

\section{Introduction}

In this chapter, a description will be given of the sample, the instruments used, the hypotheses to be tested, and the procedures to be used in the study.

\section{Population and Selection of the Sample}

A radical change in the way the Freshman English Requirement at Utah State University could be met during consecutive years enabled a relatively direct assessment of the validity of excusing students from Freshman English.

During the 1970-71 school year and for many years prior to that school year, USU had a Freshman English Requirement which could be filled only by the completion of English 101, 102 and 103 (Freshman English) or by scoring 3, 4, or 5 on the Advanced Placement test in English Composition. The first quarter of Freshman English focused on grammar, punctuation, spelling, usage, the various ways of developing an essay, etc. The second quarter was directed toward the techniques of library research, while the third quarter concentrated on writing based on short stories, poetry, essays, etc. 
Because of the 1970-71 Freshman English Requirement, most of the 1970-71 freshman class was enrolled in Freshman English during their freshman school year.

In the fall of 1971 , all freshman students who had not met the Freshman English Requirement by the Advanced Placement Test in English Composition were required to take the CLEP General Examination in English Composition. Based upon this examination, full credit for Freshman English was awarded to students who scored 450 or above, while students who scored from 390-449 were excused from Freshman English. The CLEP General Examination in English Composition is a strictly objective examination which is designed to test a student's ability to "... do the kind of writing that college students are generally asked to do ..., to recognize and solve problems of usage and grammar ... and to identify ... clear and varied sentences ..." (CEEB, 1968, p. 8).

Using both an essay test and an objective test, this study compared the writing ability of students who completed Freshman English during the 1970-71 school year when it was universally required, with the writing ability of students who completed the Freshman English Requirement by the CLEP General Examination in English Composition during the 1971-72 school year when it was universally required.

In attempting to equate the writing ability of students who had taken Freshman English with students who had completed the Freshman English Requirement by examination, a random sample of 25 students from each of four 
categories was chosen. In addition, a random sample of students who had received Advanced Placement credit in English Composition were chosen for the study. The five categories were as follows:

1. Freshman English (A-B)

The sample from this category was taken from a list containing the names, courses, and grades of the entire 1970-71 USU freshman class. Students on this list who had received credit for English 101, 102 and 103, and whose English 101-103 grade-point average was from 2.7 to 4.0 were eligible for this sample.

2. Freshman English (C-D)

The sample from this category was taken from a list containing the names, courses, and grades of the entire 1970-71 USU freshman class. Students on this list who had received credit for English 101, 102 and 103, and whose English 101-103 grade-point average was from 1.0 to 2.3 were eligible for this sample.

3. CLEP Credit

A random sample of students who took the CLEP General Examination in English Composition during the 1971-72 school year and received a score of 450 or above were selected for this category.

\section{CLEP Waiver}

A random sample of students who took the CLEP General Examination in English Composition during the 1971-72 school year and received a score of $390-449$ were selected for this category. 
5. Advanced Placement

The sample from this category was taken from a list of 197172 USU freshman students who had received a score of 3,4 , or 5 on the CEEB's Advanced Placement test in English Composition.

In choosing the various categories for the study it was assumed that the students in the Freshman English (A-B) category and the students in the CLEP Credit category were from the same population in terms of writing ability, since these groups have been treated similarly with regard to the Freshman English Requirement. Likewise, it was assumed that the students in the Freshman English (C-D) and CLEP Waiver categories were from the same population in terms of writing ability. It was also assumed that the students in the Freshman English (A-B) and CLEP credit categories had greater ability than students in the Freshman English (C-D) and CLEP Waiver categories. The students in the Advanced Placement category were assumed to be students with very high ability.

\section{Final selection of students}

A decided effort was made to obtain the participation of all students chosen in the original samples of 25 . In some instances long-distance phone calls were made to parents to locate students who could not be located otherwise. Two students refused to participate. All of the other available students from the original samples participated.

Table 1 shows the totals in each of the categories: 
Table 1. Total number in each category and number by sex

\begin{tabular}{lccc}
\hline \hline Category & No. & Men & Women \\
\hline Freshman English (A-B) & 25 & 6 & 19 \\
Freshman English (C-D) & 24 & 6 & 18 \\
CLEP Credit & 24 & 15 & 9 \\
CLEP Waiver & 23 & 6 & 17 \\
Advanced Placement & 24 & 6 & 18 \\
\hline
\end{tabular}

Although no attempt was made to select a certain proportion of each sex, etc., as shown in Table 1 , the ratio of men to women was about one to three, with the exception of the CLEP Credit category. In the CLEP Credit category the ratio of men to women was five to three.

\section{Description of Instruments Used}

The CLEP Subject Examination in $\underline{\text { English Composition (Objective Part) }}$

The objective part of the CLEP Subject Examination in English Composition (Objective Test) was included in the study to assess the students' composition abilities from an objective test designed specifically to assess students' mastery of material usually in an undergraduate college course of English 
Composition. This examination covers the following theories and principles of writing in 120 objective questions:

1. The sentence.--Questions on such matters as mechanics, usage, grammar, and the rhetorical types of sentences make up approximately 30 percent of the test.

2. The paragraph and the essay.--Approximately 15 percent of the test questions are concerned with unity, coherence, sentence variety, shifts in point of view, and modes of developing a paragraph.

3. Style.--Questions dealing with levels of abstraction of the language, figures of speech, tone, economy of statement, denotation and connotation, diction, and idiom make up about 30 percent of the test.

4. Logic in writing.--Questions about induction, deduction, logical sufficiency, and outlining constitute approximately 10 percent of the test.

5. The English Language.--Approximately 10 percent of the test is devoted to matters relating to the language such as its history, inflection, derivations, and lexicographical descriptions.

6. Library information.--About 3 percent of the test includes questions on the use of Library of Congress cards, reference books, and dictionaries.

7. Manuscript format and documentation.--Questions dealing with such matters as footnoting and bibliography make up about 2 percent of the test. (CEEB, 1970)

Scoring. The test is machine scored. Scores can range from 20 to 80 points with a mean of 50 and standard deviation of 10 . Scores are computed by subtracting a percentage of the wrong answers from the right answers.

\section{$\underline{\text { Statistical properties. }}$}

Standard Error of Measurement. The test has a standard error of measurement equal to 4 . 


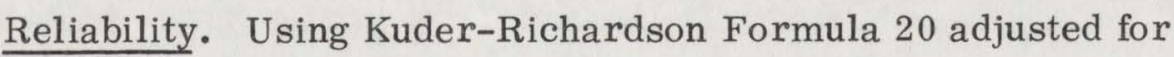
scores obtained by subtracting a percentage of the wrong answers from the right, the calculated reliability was .87 .

Content Validity. The Test was developed by Educational Testing Service Staff members working with a committee of English composition specialists from several universities. The test covers material usually covered in an undergraduate college course of English composition. (CEEB, 1970)

The CLEP Subject Examination in English Composition (Essay Part)

The essay part of the CLEP Subject Examination in English Composition (Essay Test) was included in the study to assess the students' composition abilities from a writing sample. It is composed of two sections which will be described below.

Section 1. Thirty minutes were allotted for this section. The students were asked to paraphrase a paragraph presented to them. A definition of the word "paraphrase" was given to the students immediately following the paragraph they were asked to paraphrase.

Section 2. A total of sixty minutes were allotted for the three parts of this section. Part "A" asked the students to write a paragraph using "illustration as its method of development." To write the paragraph, a list of ten items of information were given with the instructions that as little or as 
much of the information as needed could be used in writing the paragraph.

In Part B the students were told to "write a paragraph that makes use of comparison and contrast as its method of development." Ten items of information were given in Part B. The students were told that they could use as much of the information given in both Parts A and B as they needed to write the paragraph asked for in Part B. The following directions were given in Part C:

"In one of your paragraphs, but not in both, underline and label the following:

1. A complex sentence

2. A compound sentence

3. A simple sentence

In both paragraphs, underline and label those sentences which you consider to be the topic sentences." (CEEB, 1965)

Scoring. Each essay was graded independently three times--one time eacy by three members of the USU English Department. The essay graders were chosen by the Coordinator of Freshman English because he felt that they graded similarly and accurately.

The raters were asked to grade according to the instructions that were given to the students for writing each section of the essay test. (These directions have been previously reported.) In addition, the following general directions were written on the essays:

You will find below the directions for two assignments. The directions will ask you to apply to the writing of paragraphs certain techniques you have discussed in your English class. If you should find that you are not familiar with the terminology used in the directions, you should write the paragraphs anyway. 
Those who grade your papers will, of course, take into consideration your ability to organize ideas and to express them effectively in standard written English. (CEEB, 1965)

Based on the above guidelines, each grader gave an overall essay grade which could range from "F" to "A". This grade was converted to a score of from 1 to 12 points.

To insure that the papers were graded anonymously, prior to the grading the name on each essay was removed and each essay was photo-copied three times. In each of the three stacks, the essays were then shuffled and assigned numbers at random.

\section{Questionnaire}

The questionnaire was used to obtain biographical and other information from the students to further describe and differentiate the groups in the study.

The questionnaire was made up of some of the questions taken from two other questionnaires. One questionnaire was given to the sophomore norming sample for the CLEP General Examinations (Haven, 1964). The other questionnaire was given to the freshman norming sample for the CLEP General Examinations (Haven, 1967). The questions concerned the students' high school and college coursework, their future academic plans, age, year of graduation from high school, etc. (A copy of the questionnaire is included in Appendix B.) 
Additional data. In addition to the instruments used specifically to assess students' writing ability, the students' American College Test (ACT) scores and four high school grades were obtained. The ACT scores included: English, Mathematics, Social Studies, Natural Science, and Composite. One high school grade was taken from each of the following areas: English, Mathematics, Social Studies, and Natural Sciences.

\section{Procedures}

All students selected for the study were sent a letter asking them to participate. A self-addressed post card giving the times when the students could report for the study was included with the letter. (Copies of the letter and post card are included in Appendix A.) The students were asked to indicate on the post card (by checking one of the scheduled times) when they could report for the study. Students who had not returned the post card by a deadline indicated on the card, were scheduled for the study by telephone. In addition, all students were called about 24 hours prior to the time they were scheduled to participate in the study to remind them of their scheduled participation.

Because the same instruments and same procedures were used for all students in the study, the procedures will be described by instrument. 
Procedures for the questionnaire

The Questionnaire was handed to the students when they reported for the study. The students were merely asked to answer the questions and hand the questionnaire in.

Procedures for the Objective Test

After the questionnaires were handed in, the subjects were administered the Objective Test in accordance with the 1971-72 printed instructions for giving the CLEP Subject Examinations. The instructions are similar to instructions used in administering most standardized objective tests.

Procedures for the Essay Test

Following the Objective Test, the Essay Test was passed out, and students were asked to write their essays using the paper and pens that were provided. (The specific directions used for administering the Essay Test are included in Appendix C.)

\section{Hypotheses to be Tested}

In order to answer the questions presented previously, null hypotheses, where appropriate, are framed. 
1. Can essay raters rate reliably?

The answer to this question is important to the study because if the raters cannot rate reliably, then results from the rating of the essays are questionable--without reliability, validity becomes much more difficult to obtain.

An inter-rater reliability coefficient will be obtained using analysis of variance techniques.

2. Is there a difference in the Essay Test scores of the five groups who have met a Freshman English Requirement in one of the following ways: (1) scoring 3,4 , or 5 on the Advanced Placement Test in English Composition; (2) scoring 390-449 on the CLEP General Examination in English Composition; (3) scoring 450 or above on the CLEP General Examination in English Composition; (4) taking Freshman English and receiving a Freshman English grade-point average of $2.7-4.0$; (5) taking Freshman English and receiving a Freshman English grade-point average of $1.0-2.3$ ?

The answer to this question is important to the study because it should indicate the ability of the Essay Test to distinguish between the groups.

Hypothesis 1. There is no difference in the Essay Test scores of the five groups who have met a Freshman English Requirement in one of five ways. 
This hypothesis will be tested using analysis of variance techniques. If the analysis of variance $\mathrm{F}$ value is significant beyond the .05 level, Scheffe's method of parametric contrast will be used to test for significant difference between the means of the five groups.

3. When ability is held constant, is there a difference in the Essay Test scores of the five groups?

This question is asked to determine if differences that might be perceived are due to ability rather than to treatment effects.

Hypothesis 2. There is no difference in the Essay Test scores of the five groups, when ability is held constant. Analysis of covariance techniques will be used to test this hypothesis. If analysis of covariance gives an $\mathrm{F}$ value significant beyond the .05 level, Scheffe's method of parametric contrast will be used to test for significant differences between the means of the five groups.

4. Is there a difference in the Essay Test scores of students who have taken Freshman English and students who have not taken Freshman English?

The answer to this question may allow us to infer the effect of Freshman English on writing ability.

Hypothesis 3. There is no difference in the Essay Test scores of students who have taken Freshman English and students who have not taken Freshman English. 
If the analysis of variance $\mathrm{F}$ value obtained in testing hypothesis 1 is significant beyond the .05 level, this hypothesis will be tested at the .05 level using Scheffe's method of parametric contrast; if the $\mathrm{F}$ value obtained in testing hypothesis 1 is not significant, this hypothesis will not be tested.

5. When ability is held constant, is there a difference in the Essay Test scores of students who have taken Freshman English, and students who have not taken Freshman English?

The answer to this question and question 4 become important because both answers may allow us to infer the effect of Freshman English on writing ability.

Hypothesis 4. There is no difference in the Essay Test scores of students who have taken Freshman English and students who have not taken Freshman English when ability is held constant.

If the analysis of covariance $\mathrm{F}$ value obtained in testing Hypothesis 2 is significant beyond the .05 level, this hypothesis will be tested using Scheffe's method of parametric contrast; if the F value obtained in testing hypothesis 2 is not significant this hypothesis will not be tested.

6. Is there a difference in the Objective Test scores of the five groups? The answer to this question is important to the study because it should indicate the ability of the Objective Test to distinguish between the groups. 
Hypothesis 5. There is no difference in the Objective Test scores of the five groups.

Analysis of variance will be used to test this hypothesis. If an $\mathrm{F}$ value beyond the .05 level is obtained, Scheffe's method of parametric contrast will be used to test for significant differences between the group means.

7. When ability is held constant, is there a difference in the Objective Test scores of the five groups?

This question is asked to determine if differences that might be perceived are due to ability rather than to treatment effects.

Hypothesis 6. There is no difference in the Objective Test scores of the five groups when ability is held constant.

Analysis of covariance will be used to test this hypothesis. If an $\mathrm{F}$ value beyond the .05 level is obtained, Scheffe's method of parametric contrast will be used to test for significant differences between the group means.

8. Is there a difference in the Objective Test scores of the students who have taken Freshman English and the students who have not taken Freshman English?

The answer to this question may allow us to infer the effect of Freshman English on writing ability. 
Hypothesis 7. There is no difference in the Objective Test scores of the students who have taken Freshman English and the students who have not taken Freshman English.

If the analysis of variance $\mathrm{F}$ value obtained in testing hypothesis 5 is not significant beyond the .05 level, this hypothesis will be tested at the .05 level using Scheffe's method of parametric contrast; if the $\mathrm{F}$ value obtained in testing hypothesis 5 is not significant, this hypothesis will not be tested.

9. When ability is held constant, is there a difference in the Objective Test scores of the students who have taken Freshman English and the students who have not taken Freshman English?

The answer to this question and question 8 become important because both answers may allow us to infer the effect of Freshman English on writing ability.

Hypothesis 8. There is no difference in the Objective Test scores of the students who have taken Freshman English and the students who have not taken Freshman English.

If the analysis of covariance $\mathrm{F}$ value obtained in testing hypothesis 7 is significant beyond the .05 level, this hypothesis will be tested at the . 05 level using Scheffe's method of parametric contrast; if the $\mathrm{F}$ value obtained in testing hypothesis 7 is not significant, this hypothesis will not be tested. 
10. Is there a difference in the proportion of the variability of Freshman English grades that the Essay Test and the Objective Test explain?

Assuming that Freshman English grades represent a valid measure of writing ability, this question should indicate whether the Essay Test or the Objective Test is a better predictor of writing ability.

Multiple regression techniques will be used in attempting to answer this question. 


\section{CHAPTER IV}

\section{RESULTS}

The previous chapter outlined the design and procedures of the study. In addition, the sample was described. In this chapter the results will be presented in the order in which the questions and hypotheses of the study were presented in the previous chapter.

First, data regarding the Essay Test are presented. This is followed by the presentation of data concerning the Objective Test. Finally, data comparing the Essay and Objective Tests are presented.

\section{The Essay Test}

This section presents data pertaining to the Essay Test. Data regarding one question and four hypotheses are given. The hypotheses are tested at the .05 level.

The Essay Test was given to the students in the study for the following reasons: (1) to determine if students who completed Freshman English and students who did not complete Freshman English could be distinguished based on an essay test; (2) to compare the validity of an essay test and an objective test as predictors of writing ability. 
This section will attempt to provide data regarding the first purpose stated above for giving an essay test. The last section of this chapter will present data regarding the second purpose listed above for giving an essay test.

\section{Reliability}

The first question concerns whether the Essay Test was scored reliably.

The answer to this question is particularly important to the study since there is no possibility that the Essay Test scores are valid if the tests were not scored reliably--the upper limit of validity is the square root of the reliability coefficient. Therefore, the first question is:

Can raters rate reliably?

An inter-rater reliability coefficient of . 825 was obtained using analysis of variance techniques (Winer, 1962). This coefficient indicates that raters can rate reliably, and allows the possibility that the Essay Test was also read validly.

Considering the low inter-rater reliability coefficients that have generally been obtained in previous studies using essay ratings, a high Reliability coefficient was not expected. However, two factors having to do with the grading of the essays may help to explain why the papers we re graded so consistently. First, raters were selected on the recommendation of the Coordinator of Freshman English who judged them to write similarly and accurately. In addition, the raters were told to grade the papers according to the written directions that were given to the students to follow in writing the essays. Studies have shown that 
inter-rater reliability tends to increase when raters use a common set of criteria for assigning scores.

Having shown that the papers were scored reliably it is inferred that valid comparisons can be made between the groups in the study based on scores on the Essay Test. Therefore, the four hypotheses concerning the Essay Test have to do with comparisons between groups in the study.

\section{Comparison of five groups by grader}

Hypothesis 1 is:

There is no difference in the Essay Test scores of the five groups who have met a Freshman English Requirement in one of the following ways: (1) scoring 3,4 , or 5 on the Advanced Placement Test in English Composition; (2) scoring 390-449 on the CLEP General Examination in English Composition; (3) scoring 450 or above on the CLEP General Examination in English Composition; (4) taking Freshman English and receiving a Freshman English grade-point average of $2.7-4.0$;

taking Freshman English and receiving a Freshman English grade-point average of $1.0-2.3$.

Since the Essay Test was scores independently by three graders, the data regarding this hypothesis is presented separately by grader. This data is followed by a comparison of the groups when the three Essay Test scores are summed. Table 2 presents the Essay Test data from Grader 1. 
Table 2. Analysis of variance, means, standard deviations, and differences between means for grader 1

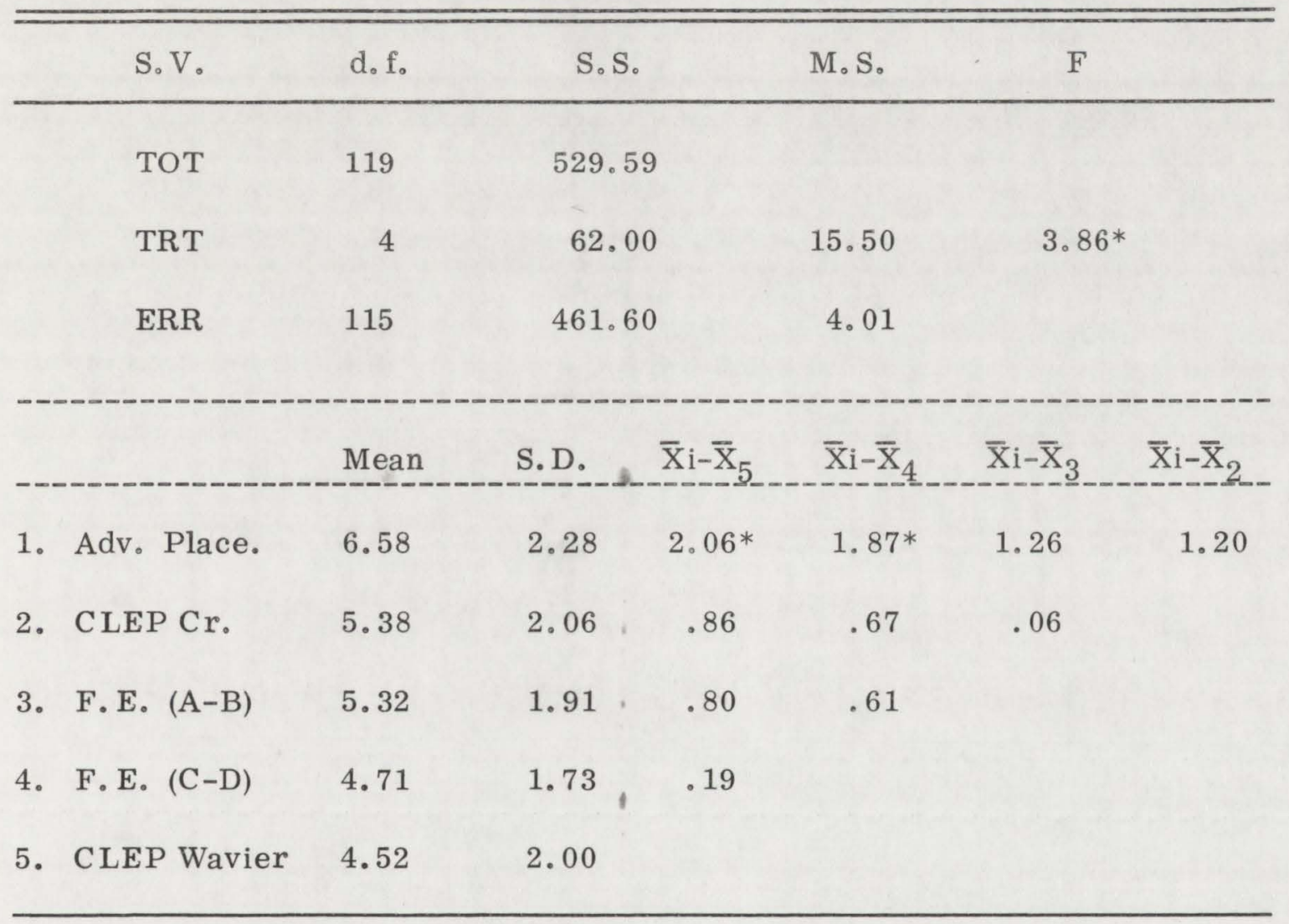

*Significant beyond the .05 level

The date in Table 2 show that Grader 1 could differentiate only between the Advanced Placement group and the two lowest groups, CLEP Waiver: and Freshman English (C-D). The Advanced Placement students received an average between $\mathrm{D}+$ and $\mathrm{C}-$.

Although there was no significant difference between the CLEP Credit group and any other group, the CLEP Credit group received a mean score 
above all groups in the study other than the Advanced Placement group, and very much like the F. E. (A-B) group.

The data for Grader 2 is presented in Table 3.

Table 3. Analysis of variance, means, standard deviations, and differences between means for grader 2

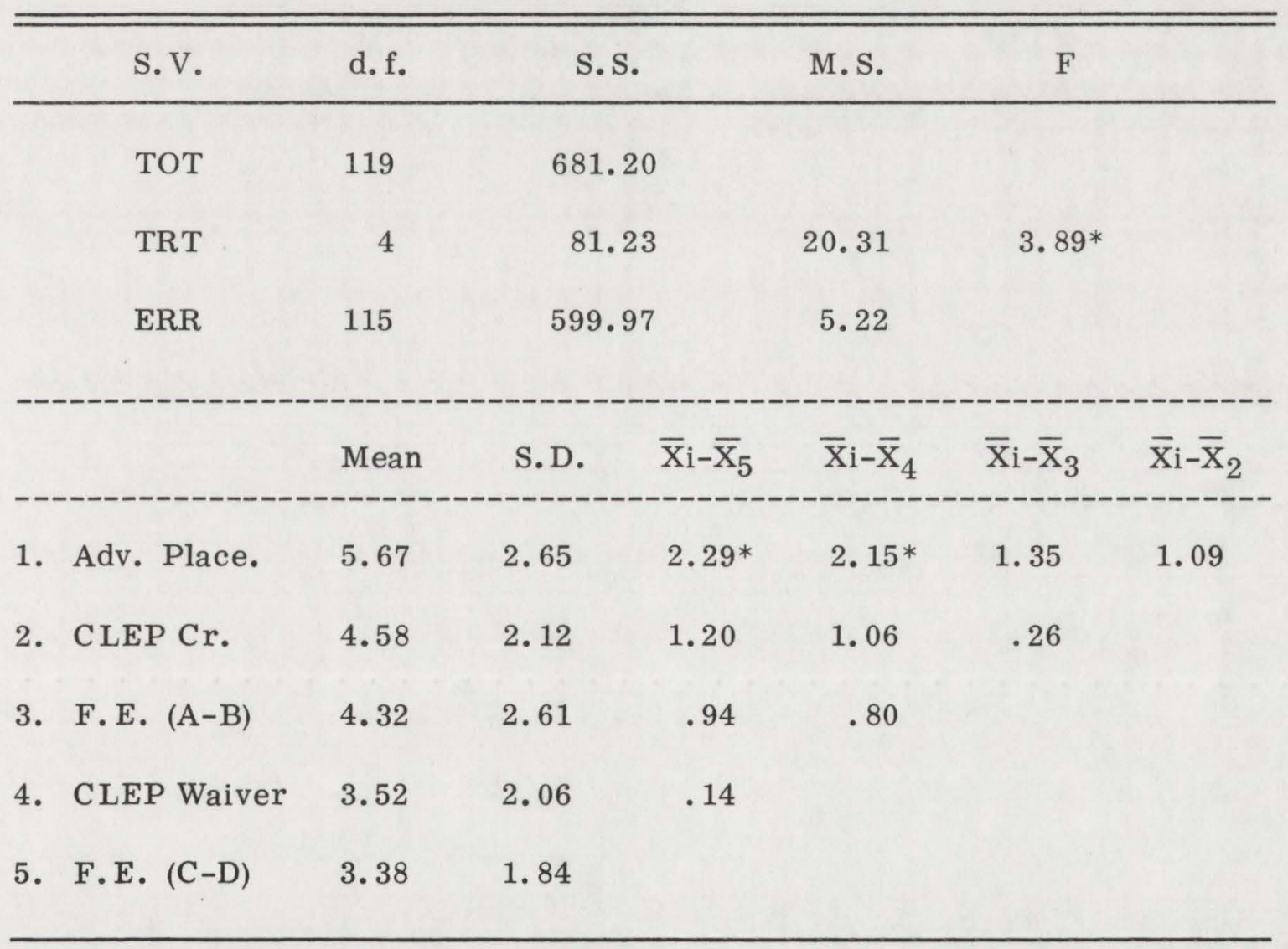

*Significant beyond the .05 level

Like Grader 1, Grader 2 could only differentiate between the top group and the bottom two groups. On the average, he gave the Advance Placement 
students between a C- and a C. The Freshman English (C-D) group received an average grade of $\mathrm{D}$ to $\mathrm{D}+$

Grader 2 also rated the essays of the CLEP Cr. group above all groups, excepting the Advanced Placement group.

Table 4 shows the data for Grader 3 .

Table 4. Analysis of variance, means, standard deviations, and differences between means for grader 3

\begin{tabular}{|c|c|c|c|c|c|c|}
\hline - S.V. & d.f. & \multicolumn{2}{|c|}{ S.S. } & M.S. & $\mathrm{F}$ & \\
\hline TOT & 119 & \multicolumn{2}{|c|}{587.97} & & & \\
\hline TRT & 4 & \multicolumn{2}{|c|}{49.02} & 12.26 & \multicolumn{2}{|c|}{$2.62 *$} \\
\hline ERR & 115 & \multicolumn{2}{|c|}{538.94} & 4.69 & & \\
\hline & Mean & S.D. & $\overline{\mathrm{X}}_{\mathrm{i}-\overline{\mathrm{X}}_{5}}$ & $\overline{\mathrm{X}} \mathrm{i}-\overline{\mathrm{X}}_{4}$ & $\overline{\mathrm{X}} \mathrm{i}-\overline{\mathrm{X}}_{3}$ & $\overline{\mathrm{X}} \mathrm{i}-\overline{\mathrm{X}}_{2}$ \\
\hline 1. Adv. Place. & 4.92 & 2.55 & 1. 75 & 1.75 & 1.04 & 1.00 \\
\hline 2. CLEP Cr. & 3.92 & 2.47 & .75 & .75 & .04 & \\
\hline 3. F.E. $(A-B)$ & 3.88 & 2.24 & .71 & .71 & & \\
\hline 4. F.E. $(C-D)$ & 3.17 & 1.63 & .00 & & & \\
\hline 5. CLEP Waiver & 3.17 & 1.75 & & & & \\
\hline
\end{tabular}


Table 4 shows that Grader 3 did not find a significant difference between any two groups in the study. However, the significant $\mathrm{F}$ value obtained is between the Advanced Placement group and the CLEP Waiver and Freshman English (C-D) groups combined. According to the mean scores given, the two lowest groups, CLEP Waiver and Freshman English (C-D), received an average of about a D grade. The highest group, Advanced Placement, averaged about a $\mathrm{C}-$.

In common with the other two raters, Grader 3 gave the CLEP Credit group the second highest mean score, which was close to the mean score given to the Freshman English (A-B) group.

Comparison of five groups by composite essay scores

Table 5 shows the groups when the scores given by the three graders are summed.

The data in Table 5 show that on the basis of the combined scores of the three essay raters, the Advanced Placement group could be distinguished from the Freshman English (C-D) and CLEP Waiver groups. There is no significant difference between the mean scores given to any of the other groups. However, the CLEP C redit group received a higher mean score than the other groups excepting the Advanced Placement group. 
Table 5. Analysis of variance, means, standard deviations, and differences between means summing scores for all three graders

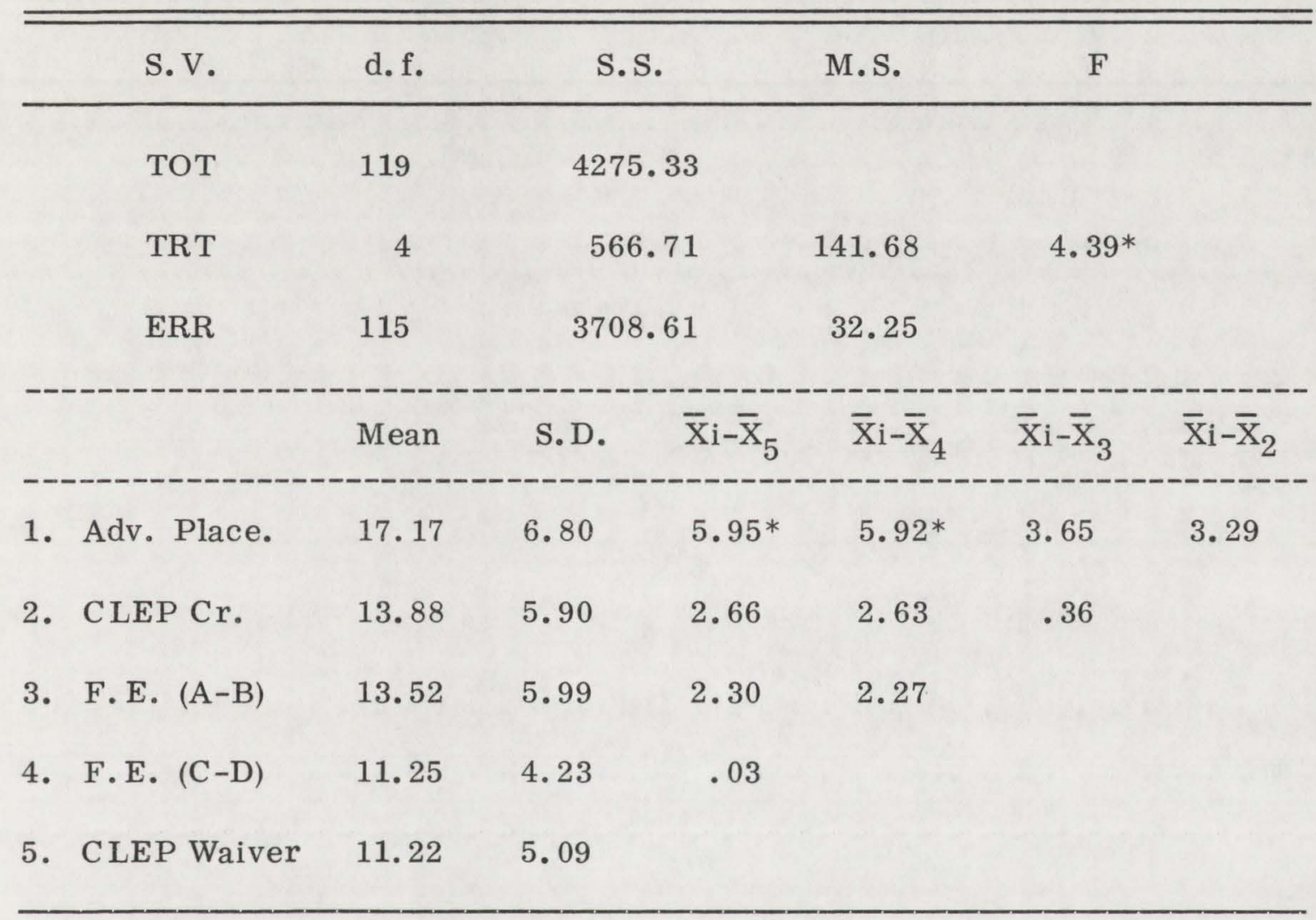

*Significant beyond the . 05 level

The data pertaining to hypothesis 1 , in general, showed significant differences between the Advanced Placement group and the CLEP Waiver and Freshman English (C-D) groups only. However, the Advanced Placement group consistently received the highest mean score and was followed by the CLEP Credit group which received a score very much like the Freshman English (A-B) group. The Freshman English (C-D) and CLEP Waiver groups consistently received very close to the same score. 
While the data regarding the first question and first hypothesis have shown that the Essay Test was scored consistently, and have shown the extent to which the Essay Test distinguishes between the five groups in the study, the second hypothesis is directed toward determining whether the groups can be separated when ability is held constant.

Comparison of five groups by composite essay score when ability is held constant

The second hypothesis is important to the study because, given certain assumptions, the effects of Freshman English may be determined.

When the groups were chosen for the study, it was assumed that the ability of the Freshman English (A-B) group was higher than the ability of the Freshman English (C-D) group. It was also assumed that the ability of the CLEP Credit group was higher than the ability of the CLEP Waiver group. The Advanced Placement group was assumed to be a very high ability group. In addition to the previous assumptions, it was assumed that the Freshman English (A-B) group and the CLEP Credit group came from the same population, and that the Freshman English (C-D) and the CLEP Wavier groups came from the same population. Given these last assumptions, when ability is held constant, any difference in writing ability between the Freshman English (C-D) and CLEP Waiver groups, or between the Freshman English (A-B) and CLEP Credit group might be inferred to be effects of Freshman English. 
The ACT Composite score is used to hold ability constant (the ACT

Composite score is the covariate in the covariance analysis) since it was the best measure of general ability available on each of the students in the study.

The second hypothesis is:

There is no difference in the Essay Test scores of the five groups, when ability is held constant.

Table 6 shows how the five groups compare when ability is held constant.

Table 6. Analysis of variance, mean and differences between means based on the composite essay test score when ability is held constant

\begin{tabular}{|c|c|c|c|c|}
\hline S. V. & d. f. & & M.S. & $\mathrm{F}$ \\
\hline TRT & 4 & & 22.01 & .78 \\
\hline REG & 1 & & 496.44 & 17.62 \\
\hline ERR & 114 & & 28.18 & \\
\hline & Mean & $\overline{\mathrm{X}}_{\mathrm{i}}-\overline{\mathrm{X}}_{5}$ & $\overline{\mathrm{X}} \mathrm{i}-\overline{\mathrm{X}}_{4}$ & $\overline{\mathrm{X}} \mathrm{i}-\overline{\mathrm{X}}_{3}$ \\
\hline 1. Adv. Place. & 14.78 & 2.54 & 1.86 & 1.57 \\
\hline 2. F. E. $(A-B)$ & 13.94 & 1.70 & 1.02 & .73 \\
\hline 3. F.E. $(\mathrm{C}-\mathrm{D})$ & 13.21 & .97 & .29 & \\
\hline 4. CLEP Waiver & 12.92 & .68 & & \\
\hline 5. CLEP Cr. & 12.24 & & & \\
\hline
\end{tabular}

*Significant beyond the . 05 level. 
The data in Table 6 show that when ability is held constant, no two groups in the study can be distinguished. Therefore, it is inferred that Freshman English has had little or nor effect on writing ability as assessed by the Essay Test.

While the two previous questions have concerned comparisons involving the individual groups in the study, the next question concerns comparisons when some of the groups are combined. The data in answer to this question were obtained by combining the Freshman English (A-B) and Freshman English (C-D) groups into one group, and by combining the CLEP Credit and CLEP Waiver students into one group. Based upon the comparison of these two "new" groups, the third hypothesis concerned whether there is a differenc in the Essay Test scores of the students who have taken Freshman English and the students who had not taken Freshman English.

Freshman English and non-Freshman

English students

Data pertaining to the third hypothesis should provide additional evidence of the effect of Freshman English. The third hypothesis is stated as follows:

There is no difference in the Essay Test scores of students who have taken Freshman English and students who have not taken Freshman English.

Table 7 presents the data from the Freshman English and non-Freshman English students. Scheffe's method of parametric contrast was used to obtain the $\mathrm{F}$ value. 
Table 7. Parametric contrast of Freshman English and non-Freshman English students on the Essay Test

\begin{tabular}{lccc}
\hline \hline & $\bar{X}$ & S.D. & F \\
\hline $\begin{array}{c}\text { Freshman English (F.E. (A-B) and } \\
\text { F. E. (C-D) }\end{array}$ & 12.41 & 5.28 & .0211 \\
$\begin{array}{c}\text { Non-Freshman English (CLEP Cr. } \\
\text { and CLEP Wvr.) }\end{array}$ & 12.57 & 5.62 & \\
& & & \\
\hline
\end{tabular}

As Table 7 indicates no significant difference was found between students who had completed Freshman English (Freshman English (A-B) and Freshman English (C-D) groups) and students who had not completed Freshman English (CLEP Credit and CLEP Waiver groups). From this datum it is also inferred that Freshman English has little or no effect on writing ability. The fourth hypothesis concerns how the Freshman English students and non-Freshman English students compare when ability is held constant.

Freshman English and non-Freshman English students when ability is held coñstant

This hypothesis is important because there remains the possibility that a significant difference will be found comparing the Freshman English and nonFreshman English students when ability is held constant. The fourth hypothesis is: 
When ability is held constant, there is no difference in the Essay Test scores of students who have taken Freshman English, and students who have not taken Freshman English.

It was not necessary to test this hypothesis since an insignificant $\mathrm{F}$ value was obtained in testing hypothesis 2 . Therefore, there is no significant difference in the Essay Test scores of Freshman English and non-Freshman English students. From this datum it is also inferred that Freshman English has little or no effect on writing ability as measured by the Essay Test.

\section{Summary of the Essay Test data}

The Essay Test was scored reliably and from this it was inferred that scores on the Essay Test served as a basis for making valid group comparisons.

When five groups were compared based on their mean Essay Test scores, the Advanced Placement group could be distinguished from the CLEP Waiver and the Freshman English (C-D) groups. The means of the other groups were not significantly different, although the groups were placed consistently with the Advanced Placement group receiving the highest mean score. The CLEP Credit group was placed second and received a mean score very much like the Freshman English (A-B) group. The CLEP Waiver and Freshman English (C-D) groups received essentially the same score.

When ability was held constant, there was no significant difference between any two of the five groups. 
When the students who had taken Freshman English were compared with students who had not taken Freshman English, no significant differences were found. This was true whether or not ability was controlled. This data was suggested as inferring that Freshman English has little or no effect on writing ability.

\section{The Objective Test}

While the previous section has considered a question and four hypotheses pertaining to the Essay Test, this section will be concerned with the four hypotheses previously presented as they pertain to the Objective Test. The hypotheses are tested at the .05 level.

The Objective Test was given to the students in the study for the same reasons the Essay Test was given. These reasons were: (1) to determine if students who completed Freshman English and students who did not complete Freshman English could be distinguished based on an objective test; (2) to compare the validity of an essay test and an objective test as predictors of writing ability.

This section will attempt to provide data regarding the first purpose stated above for giving an objective test. The last section of this chapter will present data regarding the second purpose listed above for giving an objective test.

\section{Comparison of five groups}

by objective test

The fifth hypothesis is:

There is no difference in the Objective Test scores of the five groups. 
Tables 8 and 9 show how the groups compared based on the Objective test.

Table 8. Analysis of variance, means, standard deviations and differences between means of the Objective Test

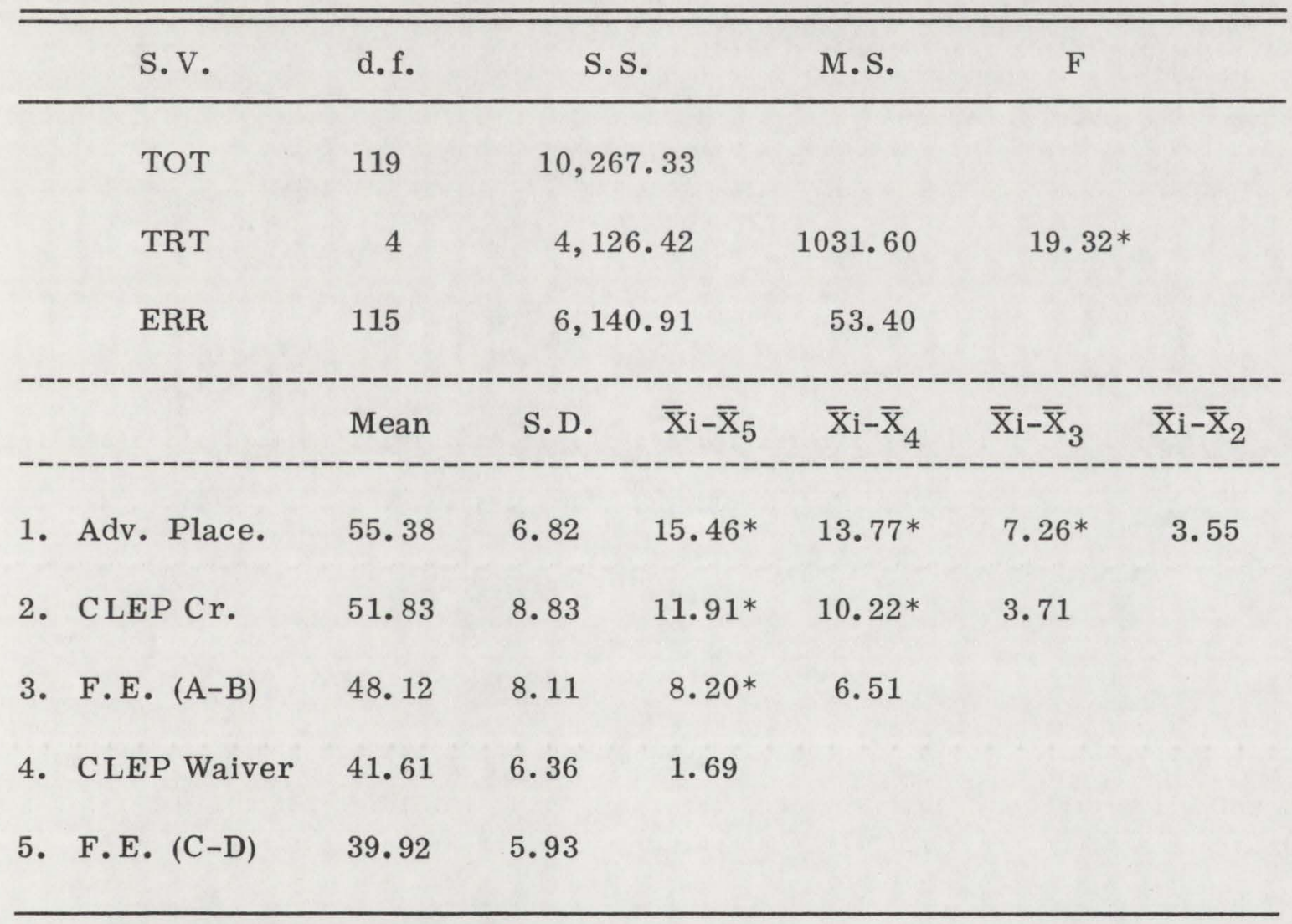

*Significant beyond the . 05 level

Since many of the differences between sample means shown in Table 8 are significant at the .05 or .01 level, Table 9 reports these significant differences separately. 
Table 9. Significant Objective Test differences

\begin{tabular}{cc}
\hline Group & Difference \\
\hline Adv. Place. vs. C-D (F. E.) & $15.46^{*}$ \\
Adv. Place. vs. CLEP Waiver & $13.77^{*}$ \\
Adv. Place. vs. A-B (F.E.) & $7.26^{*}$ \\
CLEP Cr. vs. C-D (F.E.) & $11.91^{*}$ \\
CLEP Cr. vs. CLEP Waiver & $10.22^{*}$ \\
A-B (F.E.) vs. C-D (F.E.) & $8.20^{*}$ \\
\hline
\end{tabular}

*Significant beyond the . 05 level

As shown in Table 8 and 9 most of the groups were separated by the Objective Test--six of the ten comparisons between the group means were significant. However, the relative standing of the groups is consistent with the Essay Test, and there was no significant differences between the Freshman English (C-D) and CLEP Waiver groups, or between the Freshman English (A-B) and CLEP Credit groups.

Group comparisons holding ability constant

Using the ACT Composite score to control for differences in the ability of the groups, the next hypothesis concerns how the five groups compare on the Objective Test when ability is held constant. Assuming that the Freshman 
English (A-B) group and the CLEP Credit group came from the same population, and that the Freshman English (C-D) group and CLEP Waiver group came from the same population, the data pertaining to this hypothesis should help show the effect of Freshman English. The sixth hypothesis is:

There is no difference in the Objective Test scores of the five groups when ability is held constant.

Table 10 shows how the groups compare when ability is held constant.

Table 10. Analysis of variance, means, standard deviations and differences between means on the Objective Test when ability is held constant

\begin{tabular}{|c|c|c|c|c|c|}
\hline S. V. & d. f. & & M.S. & & $\mathrm{F}$ \\
\hline TRT & 4 & & 112.84 & & $3.29 *$ \\
\hline REG & 1 & & 2239.69 & & 65.22 \\
\hline ERR & 114 & & 34.27 & & \\
\hline & Mean & $\overline{\mathrm{X}} \mathrm{i}-\overline{\mathrm{X}}_{5}$ & $\overline{\mathrm{X}} \mathrm{i}-\overline{\mathrm{X}}_{4}$ & $\overline{\mathrm{X}} \mathrm{i}-\overline{\mathrm{X}}_{3}$ & $\overline{\mathrm{X}}_{\mathrm{i}}-\overline{\mathrm{X}}_{2}$ \\
\hline 1. Adv. Place. & 50.31 & $6.24^{*}$ & 5.09 & 1.96 & 1.29 \\
\hline 2. F. E. $(A-B)$ & 49.02 & 4.95 & 3.80 & .67 & \\
\hline 3. CLEP Cr. & 48.35 & 4.28 & 3.13 & & \\
\hline 4. CLEP Waiver & 45.22 & 1.15 & & & \\
\hline 5. F.E. $(C-D)$ & 44.07 & & & & \\
\hline
\end{tabular}

*Significant beyond the .05 level 
The data in Table 10 indicate that when ability is held constant, the only significant difference between the groups is between the Advanced Placement group and the Freshman English (C-D) group. Since there was no significant difference between the Freshman English (A-B) and CLEP Credit groups, or between the Freshman English (C-D) and C LEP Waiver groups, the data regarding this hypothesis seem to infer that Freshman English has little or no effect on writing ability as measured by the Objective Test.

Freshman English and non-Freshman English students

Having shown that Freshman English has little or no effect on writing ability when the individual groups in the study are compared, the seventh hypothesis concerns whether a difference can be found between students who completed Freshman English and students who were excused from Freshman English. The data from this comparison was obtained by combining the Freshman English (A-B) and (C-D) groups into one group, and by combining the CLEP Credit and Waiver groups into one group. The seventh hypothesis is:

There is no difference in the Objective Test scores of the students who have taken Freshman English and the students who have not taken Freshman English.

Table 11 presents the data from the Freshman English and non-Freshman English students. Scheffe's method of parametric contrast was used to obtain the $\mathrm{F}$ value. 
Table 11. Parametric contrast of Freshman English and non-Freshman English students on the Objective Test

\begin{tabular}{rccc}
\hline \hline & $\overline{\mathrm{X}}$ & S.D. & $\mathrm{F}$ \\
\hline $\begin{array}{c}\text { Freshman English (F. E. (A-B) } \\
\text { and F. E. (C-D)) }\end{array}$ & 44.10 & 8.18 & 1.2243 \\
$\begin{array}{r}\text { Non-Freshman English (CLEP } \\
\text { Cr. and CLEP Waiver) }\end{array}$ & 46.83 & 9.22 & \\
\hline
\end{tabular}

As Table 11 indicates, no significant difference was found between the mean Objective Test scores of students who completed Freshman English and students who did not complete Freshman English. From this datum it is also inferred that Freshman English has little or no effect on writing ability.

Freshman English and non-Freshman English students holding ability constant

Although it has been inferred from the previous data in reference to the Objective Test that Freshman English has little or no effect on writing ability, hypothesis eight: concerns whether there is a difference in the writing abilities of Freshman English students and non-Freshman English students when ability is held constant. Data in reference to this hypothesis are important because there remains the possibility that there is a significant difference between these groups when ability is held constant. The eighth hypothesis is: 
There is no difference in the Objective Test scores of students who have taken Freshman English and students who have not taken Freshman English when ability is held constant. The data in reference to this hypothesis are presented in Table 12. The F value was obtained using Scheffe's method of parametric contrast.

Table 12. Parametric contrast of Freshman English and non-Freshman English students on the Objective Test holding ability constant

\begin{tabular}{ccc}
\hline \hline & $\mathrm{X}$ & $\mathrm{F}$ \\
\hline $\begin{array}{c}\text { Freshman English (F. E. (A-B) and } \\
\text { F.E. (C-D) }\end{array}$ & 46.60 & .0338 \\
$\begin{array}{c}\text { Non-Freshman English (C LEP Cr. } \\
\text { and CLEP Waiver) }\end{array}$ & 46.82 & \\
\end{tabular}

As shown in Table 12 there is no significant difference between those who have taken Freshman English and those who have not taken Freshman English when ability is held constant. From this datum it is also inferred that Freshman English has little or no effect on writing ability as measured by the Objective Test. 


\section{Summary of the Objective Test data}

The Objective Test distinguishes between most of the groups in the study. However, there was no significant difference between the Freshman English (C-D) and CLEP Waiver groups, or between the Freshman English (A-B) and CLEP Credit groups whether or not ability was held constant. From these data it was inferred that Freshman English has little or no effect on writing ability as measured by the Objective Test.

There was no significant difference in the writing ability of those who had completed Freshman English and those who had not completed Freshman English, whether or not ability was held constant. This was also accepted as further evidence that Freshman English has little or no effect on writing ability.

\section{Comparison of the Essay Test and the Objective Test}

While the previous sections of this chapter have considered the Essay and Objective Tests separately, this section attempts to make a direct comparison of the two tests. The ability of the two tests to predict Freshman English grades will be compared.

\section{$\underline{\text { Prediction of Freshman English grades }}$}

The second question is:

Is there a difference in the proportion of the variability of Freshman

English grades that the Essay Test and the Objective Test explain? 
The data in answer to this question are from the two groups of students in the study who took Freshman English (Freshman English (A-B) and Freshman English (C-D)). In addition to the Essay and Objective Test scores each student received, the students' ACT English, Mathematics, Social Studies, and Natural Science scores and four high school grades including the English, Mathematics, Social Studies, and Natural Science grades were used to determine the proportion of variability that could be attributed to each of these variables. Table 13 presents these data. (The complete regression analysis data is included in Appendix D.)

Table 13. Percentage of variability of Freshman English grades explained by ACT scores, high school grades, and the Essay and Objective Tests. (Listed in order of deletion from regression analysis.)

\begin{tabular}{lc}
\hline \multicolumn{1}{c}{ Variable } & $\begin{array}{c}\text { Percent of } \\
\text { explained variability }\end{array}$ \\
\hline Essay Test & .2 \\
H.S. Nat. Sci. Grade & 1.1 \\
H.S. Math. Grade & .9 \\
H.S. English Grade & 2.7 \\
ACT Soc. St. Score & 4.5 \\
ACT Nat. Sci. Score & .3 \\
ACT English Score & .2 \\
ACT Math. Score & .8 \\
ACT Composite Score & .5 \\
H.S. Soc. St. Grade & 7.6 \\
Objective Test & 21.9 \\
& -10 \\
Total & 40.7 \\
\hline
\end{tabular}


The data in Table 13 show that, of the variables included in the regression analysis, the Objective Test is the best predictor of Freshman English grades, while the Essay Test is the least useful in predicting Freshman English grades. Assuming that Freshman English grades are a valid indicator of writing ability, it can be inferred from these data that the Objective Test is a more valid measure of writing ability than the Essay Test.

Although the variables are listed in Table 13 in the order of their deletion from the regression analysis, it can be observed that the order of deletion does not always coincide with the percentage of explained variability. This can be explained by the way in which the percentage of variability is obtained-after each variable is deleted, the remaining variables in the analysis are reevaluated relative to each other. Therefore, it sometimes happens that the next variable to be deleted explains little of the remaining variance since it is highly correlated with another variable which remains in the analysis.

The data in Table 14 shows how the Essay Test and the Objective Test compare when these two variables are the only variables included in the regression analysis to predict Freshman English grades.

The data in Table 14 also indicate that the Objective Test is a better predictor of Freshman English grades than the Essay Test. It can also be observed that the Essay Test explains only an additional .4 percent of the variability explained by the Objective Test. These data confirm the findings of previous studies which have found that an essay test adds very little to the prediction of writing ability obtained from a well-made objective test. 
Table 14. Percentage of variability explained by the Essay Test and the Objective Test

\begin{tabular}{|c|c|}
\hline Variable & $\begin{array}{c}\text { Percent of } \\
\text { explained variability }\end{array}$ \\
\hline Essay Test & .4 \\
\hline Objective Test & 21.9 \\
\hline Total & 22.3 \\
\hline
\end{tabular}

Summary of comparison of Essay and Objective Tests

The Essay Test was the least useful predictor of writing ability (Freshman English grades) of a number of variables. The Objective Test was the best predictor of writing ability. From these data it was inferred that the $\mathrm{Ob}-$ jective Test is a more valid measure of writing ability than the Essay Test.

The Essay Test added only . 4 percent to the explained variability in writing ability provided by the Objective Test.

\section{Summary}

\section{Essay Test}

The Essay Test was scored reliably and, therefore, it was inferred that it served as a basis for making valid group comparisons. 
Based on the Essay Test the Advanced Placement group received the highest mean score and was followed by the CLEP Credit group who received a mean score very much like the Freshman English (A-B) group. The Freshman English (C-D) and CLEP Waiver groups received virtually identical mean scores.

It was inferred, based on the Essay Test, that Freshman English has little or no effect on writing ability since there was no significant difference between the Freshman English (A-B) and CLEP Credit groups, or between the Freshman English (C-D) and C LEP Waiver groups whether or not ability was controlled. The same inference about Freshman English was again made since there was no significant difference between students who had taken Freshman English and students who had not taken Freshman English whether or not ability was controlled.

\section{Objective Test}

Although the Objective Test showed many significant differences between the groups in the study, the relative placement of the groups based on their mean Objective Test scores was consistent with the relative standing of the groups on the Essay Test. The Advanced Placement group was first, followed in order by the CLEP Credit and Freshman English (A-B) groups. The Freshman English (C-D) and CLEP Waiver groups received essentially the same mean Objective Test score. 
There were no significant differences between either the Freshman English (A-B) and CLEP Credit groups, or between the Freshman English (C-D) and CLEP Waiver groups whether or not ability was controlled. Therefore, it was inferred that Freshman English has little or no effect on writing ability.

There was no significant difference between students who had completed Freshman English and students who had not completed Freshman English. This datum was also accepted as inferring that Freshman English has little or no effect on writing ability.

Comparison of Essay and

Objective Tests

The Objective Test was found to be a much better predictor of Freshman English grades than the Essay Test. Assuming that Freshman English grades are a measure of writing ability, it was inferred from these data that the Objective Test is a more valid measure of writing ability than the Essay Test.

Since the Essay Test explained only an additional . 4 percent of the variability in Freshman English grades that was not explained by the Objective Test, it was inferred that even a reliably scored essay test adds little to the prediction of writing ability obtained from a well-made objective test. 


\section{CHAPTER V \\ SUMMARY AND CONCLUSIONS}

\section{$\underline{\text { Problem and Objectives }}$}

The practice of excusing students from college composition courses on the basis of their performance on a strictly objective test of writing ability hás recently come into wide use. However, the review of literature has suggested that there is little direct evidence to validate the use of either an objective or an essay test of writing ability as the basis for excusing students from composition courses. The objective of this study was to more directly assess the validity of excusing students from college composition courses based on a strictly objective test of their writing ability.

A pronounced change in the way the Utah State University Freshman English Requirement could be met occurred in consecutive years. This change enabled a relatively direct assessment of the validity of excusing students from Freshman English based on the CLEP General Examination in English Composition, a strictly objective examination.

During the 1970-71 school year all freshman students at Utah State University who had not received Advanced Placement credit in English Composition were required to take Freshman English. Fall Quarter of the next year, 197172, all entering Utah State University freshman students who had not received Advanced Placement credit in English Composition were required to take the 
CLEP General Examination in English Composition, and were excused from Freshman English for scoring above 389 on this examination.

In attempting to assess the validity of excusing students from Freshman English, the Objective Test and the Essay Test were used as the criteria of writing ability. Groups of students who had taken Freshman English during the 1970-71 school year were compared with groups of students who were excused from Freshman English based on the CLEP General Examination in English Composition in the fall of 1971.

Eight hypotheses and two questions were framed which basically concerned how the groups who had completed Freshman English compared with the groups who had not completed Freshman English based on the criteria. The data relevant to the hypotheses and questions formed the bases for the assessment of the study.

Data alone do not permit conclusions and generalizations from the study. Generalizations and conclusions must also be based on the assumptions, design and rigor of the study.

Given the assumptions underlying the choice of groups for the study, the effects of Freshman English were inferred. Students who had not taken Freshman English tended to score equally as well on the criteria as students who had completed Freshman English. Given the assumption that Freshman English grades are a valid criterion of writing ability, the Objective Test was shown to be a better measure of writing ability than the Essay Test. 


\section{Limitations of the Sample}

Generalizations should not extend to groups who score below 390 on the CLEP General Examination in English Composition or to students who failed one or more quarters of Freshman English.

The ratio of males to females within the comparative groups must also be considered in making generalizations. However, the fact that the CLEP Credit group contained about twice as many men as any other group, yet, performed very well on the criteria relative to the other groups, adds support to the assessed writing ability of this group.

\section{Limitations of the Instruments}

The fact that there is really no satisfactory way of measuring writing ability is a limitation of this study as well as any study which attempts to assess writing ability.

The fact that the grades given to the five groups in the study only ranged from approximately a "C" to a " $\mathrm{D}$ " may be due to the Essay Test per se since the Advanced Placement students had been judged, previous to the study, as being capable writers based on criteria which had included an essay test. 


\section{Other Limitations}

This study investigated only one type of Freshman English program. The findings, of course, may not apply to another type of Freshman English.

\section{Conclusions}

In view of the above limitations and using the Essay and the Objective tests as the criteria of writing ability, it seems safe to conclude that students who were excused from Freshman English based on the CLEP General Examination in English Composition write as well as students who completed Freshman English, and there is no difference in the writing abilities of the Freshman English (A-B) and CLEP Credit students, or between the Freshman English (C-D) and CLEP Waiver students. In view of these conclusions, it seems safe to conclude that the assumptions regarding the selection of the Freshman English and non-Freshman English groups are valid, and the CLEP General Examination in English Composition has been accurately applied at Utah State University.

Based on the assumption that Freshman English grades are a valid criterion of writing ability, it is concluded that the Objective Test is a more valid measure of writing ability than the Essay Test, and further concluded that the Objective Test can predict writing ability quite accurately independent of the Essay Test. In consideration of these two conclusions and a previous conclusion that the CLEP General Examination in English Composition has been 
accurately applied at Utah State University, it is also concluded that a strictly objective test can validly be used to excuse students from freshman composition courses.

\section{$\underline{\text { Implications }}$}

The present study represents a relatively direct assessment of the validity of granting college composition credit based on the CLEP General Examination in English Composition. Based on the data obtained, the CLEP General Examination in English Composition should continue to be used to meet the English part of the Utah State University Communications Requirement.

\section{Recommendations for Further Research}

Since the data were gathered for this study, Utah State University has begun awarding different amounts of composition credit for various scores on the CLEP General Examination in English Composition. A study of this "new" program would seem appropriate.

Although the present study has investigated relatively short-term effects of Freshman English, a study of the long-term effects of Freshman English may be appropriate.

A study of the effects of other freshman composition programs may also be worthwhile. 
Recommendations for further research may be grouped into these areas: multiple cut-offs for awarding composition credit; long-term effects of Freshman English; effects of other programs of freshman composition. 
BIBLIOGRAPHY

Anastasi, Ann。1969. Psychological Testing. Third Edition. The MacMillan Co., Collier-MacMillan Ltd., London.

Angoff, William H. and Henry S. Dyer. 1971. The Admissions Testing Program。 In Angoff, William H。(ed。). The College Board Admissions Testing Program: A Technical report on research and development activities relating to the Scholastic Aptitude Test and Achievement Test. College Entrance Examination Board, Princeton, New Jersey。

Anderson, C。C . 1960。 The New STEP Essay Test as a Measure of Composition Ability. Educational and Psychological Measurement 20:95-102.

Beck, Robert H. 1968. An Investigation of Relative Performance Factors in Freshman English at Wisconsin State University. Office of Education, Washington, D. C.

Becker, George. 1972. An Evaluation of an Innovative Approach to English Composition Instruction. Phase One. Long Beach City College, California.

Braddock, Richard and Charles R. Statler. 1968. Evaluation of CollegeLevel Instruction in Freshman Composition, Part II. University of Iowa, Iowa City. U.S. Office of Education.

Braddock, Richard, Richard Lloyd-Jones and Lowell Schoer. 1963. Research in Written Composition. National Council of Teachers of English, Champaign, Illinois.

Braddock, Richard. 1969. English Composition. In Ebel, Robert L. and Victor H. Noll (eds.). Encyclopedia of Educational Research, 4th edition, MacMillan.

Bracht, Glenn H. and Kenneth D. Hopkins. 1970. The Communality of Essay and Objective Tests of Academic Achievement. Educational and Psychological Measurement 30:359-364.

Britton, J. N. and others. 1966. Multiple Marking of English Compositions: An Account of an Experiment. Schools Council, London, England. 
Buggs, Mary Jo. 1969. The Wisconsin State University Stevens Point Freshman Composition Project. Wisconsin State Universities Consortium of Research Development, Stevens Point. Office of Education, Washington, D.C.

Burkett, Eva. 1971. Composition Tests for Screening Prospective Teachers. College Composition and Communication 22:355-362.

Burman, Ronald S. and Lorraine Flaherty. 1968. The 1967 Freshman English Program at Wisconsin State University at La Crosse. Office of Education, Wa shington, D. C.

Burton, Dwight L. and Lois V. Arnold. 1963. Effects of Frequency of Writing and Intensity of Teacher Evaluation upon High School Students' Performance in Written Composition. Tallahassee, Florida: Forida State University.

Buxton, Earl W. 1958. An Experiment to Test the Effects of Writing Frequency and Guided Practice upon Students' Skill in Written Expression. Unpublished Ph. D. dissertation, Stanford University. (As reported in Braddock, Richard and Richard Lloyd-Jones and Lowell Schoer. 1963. Research in Written Composition. Champaign, Illinois: National Council of Teachers of English.)

Chapman, Gloria O. 1961. The Effects of Acceleration on Social and Academic Achievement. Journal of Higher Education 32:143-148.

Coffman, William E. 1961. Sex Difference in Responses to Items in an Aptitude Test. Eighteenth Yearbook, National Council on Measurement in Education.

Coffman, William E. 1969. Achievement Tests. In Ebel, Robert L. and Victor H. Noll (eds.). Encyclopedia of Educational Research, 4th edition, Macmillan.

Coffman, William E. and D. Kurfman. 1968. A Comparison of Two Methods of Reading Essay Examinations. American Educational Research Journal, 5:99-107.

Cohen, Arthur M. 1971a. Factors Accounting for the Variance in Junior College Students' Composition Writing. School of Education, California University, Los Angeles, California. National Center for Educational Research and Development, Washington, D.C. 
Cohen, Arthur M. 1971b. A Procedure for Assessing Students' Ability to Write Compositions. Paper presented at the Annual Meeting of the California Educational Research Association, April 29-30, 1971, San Diego, California.

College Entrance Examination Board. 1968. Candidates Tested Through the U.S. Armed Forces Institute. New York: College Board.

College Entrance Examination Board. 1970. A Description of the Subject Examination, College-Level Examination Program. 1970. College Entrance Examination Board.

Committee on Measurement and Evaluation of College Testing. 1959. A Guide to Practices and Programs. Washington, D.C.: American Council on Education.

Cooley, W. W. and P. R. Lohnes. 1962. Multivariate Procedures for the Behavioral Sciences. John Wiley and Sons, Inc., New York.

Cowles, John T. and John P. Hubbard. 1952. A Comparative Study of Essay and Objective Examinations for Medical Students. Journal of Medical Education 27:14-17.

Denby, Robert V. 1968. NCTE/ERIC Report: Composition Evaluation. English Journal 57:1215-1221.

Derrick, C. 1964. Tests of Writing. English Journal 53:496-499.

Diederich, Paul B. 1966. How to Measure Growth in Writing Ability. English Journal 55:435-449.

Di Russo, Lawrence, and Samuel D. Aven. 1971. Does Remedial English Help for College Freshmen. California Journal of Educational Research 22:5-8.

Diederich, Paul B. 1967. Cooperative Preparation and Rating of Essay Tests. English Journal 56:573-584.

Dole, A. A. 1951. Evidence for the Effectiveness of a Program for Giving College Credit by Examination. Educational and Psychological Measurement 2:387-396.

Dressel, Paul and John Schmid, Jr. and Gerald Kincaid. 1952. The Effect of Writing Frequency upon Essay-Type Writing Proficiency at the College Level. Journal of Educational Research XLVI:285-293. 
ETS Builds a Test. 1965. Educational Testing Service, Princeton, New Jersey.

Fradule, James J. Jr. 1969. An Experimental Study of the Effectiveness of the Developmental English Course and the Selection Process for Classifying Developmental English Students at Lehigh County Community College. Ed. D. dissertation, Lehigh University.

Farrell, Edmund J. 1971. Implications of National Assessment Writing Results. Speech given at the Annual Meeting of the Association of American Publishers, Inc. Washington, D. C.

Ferguson, George A. 1971. Statistical Analysis in Psychology and Education. Third Edition. McGraw-Hill, Inc., New York.

Findley, Warren G. 1972. CLEP General Examination in English Composition. In Buros, Oskar K. (ed.). The Seventh Mental Measurements Yearbook, Vol. I. The Gryphon Press, Highland Park, New Jersey.

Finlayson, Douglas S. 1951. The Reliability of the Marking of Essays. British Journal of Educational Psychology XXI:126-134.

Fisher, R. A. 1936. The Use of Multiple Measurements in Taxonomic Problems. Annals of Eugenics 7:179-188.

Flaugher, Ronald L., Margaret H. Mahoney, and Rita B. Messing. 1967. Credit by Examination for College-Level Studies: An Annotated Bibliography. College Entrance Examination Board, New York.

Fletcher, H. 1932. Proficiency Examinations for Credit at the University of Illinois. School and Society 36:792-793.

Fostvedt, Donald R. 1965. Criteria for the Evaluation of High School English Composition. Journal of Educational Research 59:108-112.

Fremer, John and Marjorie D. Chandler. 1971. Special Studies. In The College Board Admissions Testing Program: A Technical Report on Research and Developmental Activities Relating to the Scholastic Aptitude Test and Achievement Tests.

French, John W. 1956. The Effect of Essay Tests of Students Motivation. Research Bulletin 56-4. Princeton, New Jersey: Educational Testing Service. (As reported in Angoff, William H. and Henry S. Dyer. 1971. The Admissions Testing Program.) 
French, John W. 1957. What English Teachers Think of Essay Testing. English Journal XLVI:196-201.

French, John W. 1961. Schools of Thought in Judging Excellence of English Themes. In Anastasi, Anne (ed.). Testing Problems in Perspective. Twenty-Fifth Anniversay Volume of Topical Readings from the Invitational Conference on Testing Problems.

Garrett, A. B. 1946. Giving College Credit in Chemistry by Examination. Ohio Schools 24:356-357.

Glass, Gene V. and Julian C. Stanley. 1970. Statistical Methods in Education and Psychology. Prentice-Hall, Inc., New Jersey.

Godshalk, Fred I., Francis Swineford, and William E. Coffman. 1966. The Measurement of Writing Ability. College Entrance Examination Board, New York.

Goolsby, T. M. 1966. The Validity of a Comprehensive College Sophomore Test Battery for Use in Selection, Placement, and Advisement. Educational and Psychological Measurement 26:977-983.

Goolsby, Thomas M. 1970. The Validity of the CLEP Tests for Use at the College Sophomore Level. Educational and Psychological Measurement $30: 375-380$.

Greene, Harry A. and Walter T. Petty. 1963. Developing Language Skills in the Elementary Schools. Boston: Allyn and Bacon, Inc.

Haak, L. A. 1953. Acceleration by Examination. College and University $29: 39-52$.

Harris, David P. 1972. The CLEP Subject Examination in English Composition. In Buros, Oscar Krisen (ed.). The Seventh Mental Measurement Yearbook. Rutgers University Press, New Brunswick.

Haven, E. W. 1964. The Sophomore Norming Sample for the General Examinations of the College-Level Examination Program Statistical Report 64-63. Princeton, New Jersey: Educational Testing Service.

Haven, E. W. 1967. The Freshman Norms for the General Examinations of the College-Level Examination Program Statistical Report 67-32. Princeton, New Jersey: Educational Testing Service. 
Heys, Frank Jr. 1962. The Theme-a-Week Assumption: A Report of an Experiment. The English Journal LI:320-322.

Hillerich, Robert L. 1971. Evaluation of Written Language. Elementary English 48:839-842.

Hipple, T. W. 1972. The Grader's Helpers: Colleagues, Peers, Score Cards. English Journal 61:690-693.

Huddleston, Edith M. 1954. Measurement of Writing Ability at the CollegeEntrance Level: Objective vs. Subjective Testing Techniques. Journal of Experimental Education 22:165-213.

Hurst, Rex L. 1970. Qualitative Variables in Regression Analysis. American Educational Research Journal 7:541-552.

Hurst, Rex L. 1972. Statistical Program Package. Utah State University.

Jewell, Ross M., John Cowley and Gerald Bisby. 1966. The Effectiveness of College-Level Instruction in Freshman Composition. State College of Iowa, Cedar Falls.

Jewell, Ross M., John Cowley and Gordon Rhum. 1969. The Effectiveness of College-Level Instruction in Freshman Composition. University of No. Iowa, Cedar Falls. U.S. Office of Education.

Jewell, Ross M., John Cowley, Gerald Bisby. 1970. Instruction in College Freshman Composition. Northern Iowa University, Cedar Falls. Office of Education, Washington, D. C. Bureau of Research.

Jones, E. S. and Gloria K. Ortner. 1954a. College Credit by Examination: An Evaluation of the University of Buffalo Program. The University of Buffalo Studies 21:127-201.

Jones, E. S. and Gloria K. Ortner. 1954b. Advanced Standing for Superior Students. National Educational Association Journal 43:107-108.

Kincaid, Gerald L. 1953. Some Factors Affecting Variations in the Quality of Students' Writing. Unpublished Ed. D. dissertation, Michigan State University. As reported in Braddock, Richard, and Richard LloydJones and Lowell Schoer. 1963. Research in Written Composition. National Council of Teachers of English. Champaign, Illinois. 
Knickerbocker, K. L. 1951. Placement of Freshmen in First-Quarter English. Journal of Higher Education 22:211-215.

Kitzhaber, Albert R. 1963. Themes, Theories and Therapy: The Teaching of Writing in College. McGraw-Hill, New York.

Lindell, Ebbe. 1971. Composition in the Intermediate State of the Comprehensive School. Stockholm School of Education. Institute of Educational Psychology.

Loak, John. 1971. Do Remedial Programs Really Work? Paper presented at the Annual Meeting of the American Educational Research Association, New York, New York.

Logan, Carolyn. 1970. Myth and Method. English Journal 59:548-550.

Lokke, Virgil L. and George S. Wykoff. 1948. Double Writing in Freshman Composition: Experiment. School and Society LXVIII:437-439.

Maize, Ray C. 1954. A Study of Two Methods of Teaching English Composition to Retarded College Freshmen. Journal of Educational Psychology XLV:22-28.

Maize, Ray C. 1954. A Writing Laboratory for Retarded Students. College English XVI:44-48.

Marascuilo, Leonard A. 1971. Statisticsl Methods for Behavioral Science Research. McGraw-Hill, Inc., New York.

Marshall, Jon C. and Jerry M. Powers. 1969. Writing Neatness, Composition Errors, and Essay Grades. Journal of Educational Measurement $6: 97-101$.

Martin, Walter D. 1970. Applying and Exploring the Diederich Method of Measuring Growth in Writing Abilities in High School (Vinton). $\mathrm{Ph}$. D. dissertation, University of Iowa.

McColly, William. 1970. What Does Educational Research Say about the Judging of Writing Ability? The Journal of Educational Research 64:148-156.

McColly, William and Robert Remstad. 1963. Comparative Effectiveness of Composition Skills Learning Activities in the Secondary School. Madison, Wisconsin, University of Wisconsin. 
McColly, William and Robert Remstad. 1965. Composition Rating Scales for General Merit: An Experimental Evaluation. Journal of Educational Research 59:55- .

Miller, Robert G. 1960. Selecting Variates for Multiple Discriminant Analyses. The Travelers Weather Research Center. Hartford, Connecticut.

Modu, Christopher C. 1972. The Effectiveness of an Essay Section in the American History and Social Studies Test. Educational Testing Service, Princeton, New Jersey.

Monson, Dianne L. 1971. Evaluation: Quantity and Quality. Elementary English 48:495-500.

Myers, Albert E. and Carolyn B. McConville and William E. Coffman. 1966. Simplex Structure in the Grading of Essay Tests. Educational and Psychological Measurement 26:41-54.

Nelsen, Laurence E. 1967. Sequential Composition Grading. Clearing House 41:434.

Newberry, R. A. 1967. Objective Indices in the Assessment of Essays. British Journal of Educational Psychology 37:403-405.

Newcomb, Mary J. 1970. An Experimental Study of Freshmen English on the Small Community Junior College Using Disparate Methods of Instruction. Ph. D. dissertation, University of Kansas.

Noyes, Edward S. 1961. Teaching and Testing of English. College Composition and Communication 12:37.

Noyes, Edward S. 1949. Review of Cooperative English Test. In Buros, Oscar Krisen (ed.). The Third Mental Measurement Yearbook. Rutgers University Press, New Brunswick.

Noyes, Edward S. 1963. Essay and Objective Tests in English. College Board Review 49:?

Nunnally, Jum C. 1967. Psychometric Theory. McGraw-Hill, New York.

Off-Campus Studies to Earn Credits. The New York Times. October 8, 1963.

Palmer, Orville. 1961. Sense or Nonsense? The Objective Testing of English Composition. The English Journal 50:314-320. 
Palmer, Orville. 1960. Sixty Years of English Testing. College Board Review 42:8-14.

Pidgeon, D. A. and A. Yates. 1957. Symposium: The Use of Essays in Selection at 11+. IV: Experimental Inquiries into the Use of Essay Type English Papers. British Journal of Educational Psychology 27:37-61.

Pilliner, A. E. G. 1969. Multiple Marking: Wiseman or Cox? British Journal of Educational Psychology 39:313-315.

Pressey, S. L. 1949. Educational Acceleration: Appraisals and Ba sic Problems. Ohio State University Studies, Bureau of Educational Research Monographs, No. 31. Columbus, Ohio: Ohio State University. (As reviewed in Flaugher et al. 1967. Credit by Examination for CollegeLevel Studies: An Annotated Bibliography. College Entrance Examination Board, New York.)

Pressey, S. L. 1945. Credit by Examination: Present Use and Future Need. Journal of Educational Research 38:596-605.

Remondino, C. 1959. A Faster Analysis of the Evaluation of Scholastic Composition in the Mother Tongue. British Journal of Educational Psychology 29:242-251.

Rothney, John W. M. 1965. What Research Says to the Teacher. Evaluation and Reporting Pupil Progress. Department of Classroom Teachers. American Educational Research Association, National Education Association.

Schneider, Virginia L. 1970. A Study of the Effectiveness of Emphasizing the Teaching of Reading Skills to Improve Composition Skills in Remedial English Classes at Kansas City Kansas Community Junior College. Ph.D. dissertation, University of Kansas.

Scannell, Dale P. and Jon C. Marshall. 1966. The Effect of Selected Composition Errors on Grades Assigned to Essay Examinations. American Educational Research Journal 3:125-130.

Schuler, S. 1965. AP, Bright Tone in Education. PTA Magazine 59:4-7.

Schumann, Paul F. 1968. What Criteria do You Use in Grading Compositions? English Journal 57:1163-1165. 
Sears, Mary O. 1970. Effects of a Students Centered Procedure on the Self-Concepts and Writing Practice of College Freshmen. Ph. D. dissertation. Florida State University。

Sharon, Amiel T. 1971a. The Use and Validity of the GED and CLEP Examinations in Higher Education. Paper presented at the Annual Conference of the American Personnel and Guidance Association, Atlantic City, New Jersey, April 6, 1971.

Sharon, Amiel T. 1971b. Measurement of College Achievement by the CollegeLevel Examination Program. Educational and Psychological Measurement $31: 477-484$.

Sharon, Amiel T. 1970. Measurement of College Achievement by the CollegeLevel Examination Program. Educational Testing Service, Princeton, New Jersey.

Smith, Vernon H. 1970. Do-It-Youself Test: How do you Rate as a Judge of Children's Writing? Elementary English 47:346-348.

Stalnaker, John M. 1933. Essay and Objective Writing Tests. English Journal (College Edition) 22:222.

Stalnaker, John M. and R. C. Stalnaker. 1934. Reliable Reading of Essay Tests. Scholastic Research 42:599-605.

Storey, Arthur G. 1968. Some Evidence in the Essay-Item Case. Journal of Educational Research 61:350-354.

Thorndike, Robert and Elizabeth Hagen. 1969. Measurement and Evaluation in Psychology and Education. John Wiley and Sons, Inc., New York, 3rd Edition.

Underwood, Jean L. 1969. Factors Affecting Differences in Quality and Style of Writing in College Freshman Examinations. Ed.D. dissertation, University of Oregon.

Vacchiano, Ralph B. and Robert J. Adrian. 1966. Multiple Discriminant Style of Writing in College Freshman Examinations. Ed.D. dissertation, University of Oregon.

Veal, L. Ramon and Edieann F. Biesbrook. 1971. Primary Essay Tests. Journal of Educational Measurement 8:45-46. 
Vogler, S. H. 1971. Grading Themes: A New Approach; A New Dimension. English Journal 60:70-74.

Wahlberg, William A. 1970. The Effect of Process Intervention on the Attitudes and Learning in a College Freshman Composition Class. Ph. D. dissertation, University of Michigan.

Ward, F. C. 1950. The Idea and Practice of General Education. Chapter 11, "Examining," by Benjamin Bloom, Jane Allison, and Paul B. Diederich. Chicago: University of Chicago Press.

Winer, B. J. 1962. Statistical Principles in Experimental Design. McGrawHill Book Co., Inc., New York.

Wiseman, Stephen and Jack Wrigley. 1958. Essay Reliability: The Effect of Choice of Essay Title. Educational and Psychological Measurement 18:129-138.

Yonge, George D. 1965. Students. Review of Educational Research 35: 253-263. 

92

Appendix A

$\underline{\text { Letter and Postcard Sent to Students }}$ 
OFFICE OF THE

VICE PRESIDENT

\author{
April 6, 1972
}

\title{
Dear
}

The University has made some significant changes in some of its policies during the current school year. At the present tine, we are examining the program of granting credit by examination. In this connection, we are conducting a study to determine the role of exarninations in awarding credit for Freshmen English by examination.

"Ve hive selected you to participate in this study. We need you to take an examination in english composition, which has not reviously been given at USU. This test, which will require about three hours to complete, will be fiven at the following times:

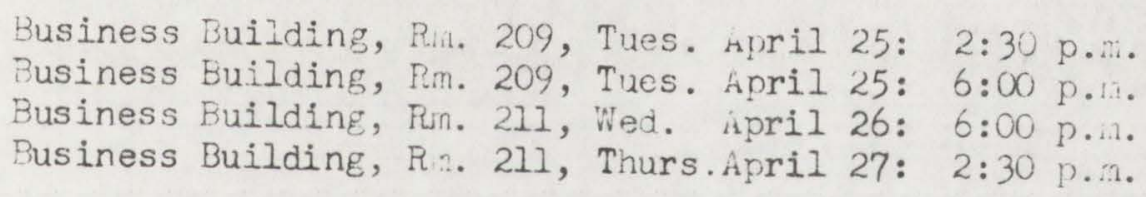

Please fill out the enclosed post card and mail it prior to ipril 17, indicating when you will take the examination, so that we can be prepared for you. If you have any questions, call 752-4100, extension 7591, or come to Roon 2 in the Old Main Building.

This study will make an important contribution to the University. As a token of appreciation for your participation, you will receive a $\$ 5.00$ honorarium for completing the test.

Thank you very much for your help.

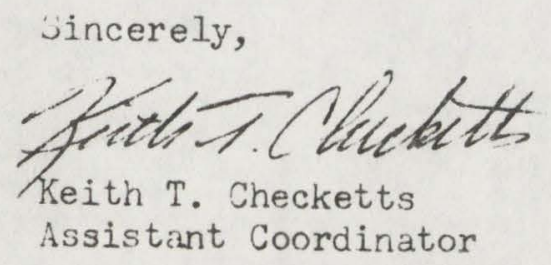




\section{Postcand Sent To Students}

Dr. Keith T. Checketts

Main \#2 Counseling \& Testing

Utah State University

Logan, Utah 84321

I will report for the examination: (Check one)

Business Building, Rm. 209, Tues. Apr. 25 2:30 p. m. Business Building, Rm. 209, Tues. Apr. 25 6:00p.m. Business Building, Rm. 211, Wed. Apr. 26 6:00p. m. Business Building, Rm. 211, Thur Apr. 27 2:30p.m.

Please reply before April 17.

NAME

ADDRESS 
95

Appendix B

The Questionnaire 
QUESTIONNAIRE

1. Please 1ndicate sex.
(A) Male
(B) Female

2. What is your age, in years, as of your last birthday?
(A) 18 or less
(B) 19
(C) 20
(D) 21
(E) 22 or more

3. Year of graduation from high school?
(A) Prior to 1968
(B) 1968
(C) 1969
(D) 1970
(E) 1971 or 1 ater

4. On the basis of your grades, which of the following best describes your academic standing in your high school graduating class?
(A) In the top ouarter
(B) In the second quarter
(C) In the third quarter
(D) In the lowest quarter

5. In your high school work (grades 9-12), how many academic years of English did you complete?
(A) 4 years or more
(B) 3/y years
(C) 3 years
(D) Less than 3 years

6. In your high school work (grades a - 12) how many academic years of Mathematics did you complete?
(A) 4 years or more
(B) 3 or $3 \frac{2}{4}$ years
(C) 2 or $2 \frac{1}{4}$ years
(D) 1 or $1 \frac{1}{2}$ years
(E) Less than 1 year

7. In your high school work (grades 9-12), how many academic years of Forelgn Language (both classical and modern) did you complete? (If you took more than one language, give the total time for all languages.)
(A) 7 years or more
(B) 4 to $6 \frac{1}{5}$ years
(C) 3 or $3 \frac{1}{2}$ years
(D) 2 or $2 \frac{1}{4}$ years
(E) Less than 2 years 
8. In your high school work (grades 9-12) how many academic years of Science did you complete?
(A) 4 years or more
(B) 3 or $3 \frac{1}{2}$ years
(C) 2 or $2 \frac{1}{3}$ years
(D) 1 or $1 \frac{1}{2}$ years
(E) Less than 1 year

9. In your high school work (grades 9-12), how many academic years of Social Studies and History (e.g., Civics, Geography, Economics, etc.) did you complete?
(A) 4 years or more
(B) 3 or $3 \frac{1}{2}$ years
(C) 2 or $2 \frac{1}{3}$ years
(D) 1 or $1 \frac{1}{2}$ years
(E) Less than 1 year

For each of the following troad fields of study (Questions 10-14) mark:

" $A$ " for the one area in which you will have completed the most

" $B$ " college courses to this date in college.

" $B$ " for any other areas in which you w1ll have completed one or more courses.

" $C$ " for any areas in which you have had no courses.

\section{Eng118h}
(A)
(B)
(C)

11. Humanities (including Forelgn Language, Fine Arts, Mus1c, Philosophy, Religion, Art)
(A)
(B)
(C)

12. Mathematics
(A)
(B)
(C)

13. Physical and Blological Sclences
(A)
(B)
(C)

14. Mistory and Social Sciences
(A)
(B)
(C) 
15. During the past week, how many hours did you spend in studying for courses exclusive of time spent in class? If the last week was not typical, give the number of hours in a typical week.
(A) Less than 10 hours
(B) 10 to 14 hours
(C) 15 to 24 hours
(D) 25 hours or more

16. During the past week, how many hours did you spend in paid employment? If the last week was not typical, give the number of hours in a typical week.
(A) Less than 1 hour
(B) 1 to 7 hours
(C) 8 to 16 hours
(D) 17 to 24 hours
(E) 25 hours or more

17. Which of the following most nearly describes your chief reason for coming to college?
(A) I wanted to make social contacts and develop my social sk111s.
(B) I wanted to prepare myself for a better-paylng job than I would otherwlse he able to get.
(C) A college degree is necessary in order to enter the profession I have chosen.
(D) I wanted to Increase my general knowledge.
(E) I wanted a chance to find out what line of work I would be most interested in.

18. Which of the following best describes the relation of your present college plans to a possible career in teaching?
(A) I w11l probab1y not prepare to teach.
(B) I will probably prepare to teach in elementary school.
(C) I w11l probably prepare to reaeh in secondary school.
(D) I w1ll probably prepare to teach in a college or university.

19. Do you plan to go on to a graduate or professional school (e.g., law, medicine, business, etc.) after college?
(A) Yes
(B) No
(C) Undecided

20. Which of the following areas best describes the main emphasis in your plars for education beyond the present academ1c year? (Please mark only ne of the undergraduate areas listed even though more than one may seem applicable.)
(A) Do not plan to continue beyond the present academic year
(B) Agriculture (1ncluding Agronomy, Agricultural Fconomics, Forestry, Solls, etc.)
(C) Blological Sciences (Including Rotany, Pre-Dental, Pre-Medical, etc.)
(D) Business (including Accounting, Bus. Administration, Marketing, Finance, Industrial Management, etc.)
(E) Education (Including Elementary Fducation, Business Fducation, Physical Education, etc.)


20 continued

(F) Engineering (including Chemical Englneering, Civil Fnglneering, Electrical Engineering, Mechanical Engineering, etc.)

(G) Home Economics (including Dietetics, Family and Child Development, Nutrition, Textiles and Clothing, etc.)

(H) Humanities and Fine Arts (1ncluding English, Fine Arts, Modern and Class1cal Fore1gn Languages, Journa11sm, Music, Philosophy, Peligion, etc.)

(I) Physical Sciences (including Astronoury, Blochemistry, Chemistry, Geology, Phys1cs, etc.)

(J) Mathemat1cs

(K) Soclal Sciences (Including Fconomics, Government, History, Polftical Science, Pre-Law, Soclology, etc.)

(L) Undecided

(M) Other

21. Which of the following most nearly describes your feeling about your high school preparation for the college work you have completed?

(A) My high school preparation was excellent.

(B) My high school preparation was good.

(C) My high school preparation was satisfactory.

(D) My high school preparation was falr.

(E) My high school preparation was poor.

22. Of the courses you have had in college, how many have you found really interesting?
(A) None of them
(B) Some, but less than half
(C) About half of them
(D) Most of them
(E) A11 of them

23. Which one of the following do you consider your strongest academic area?
(A) Eng11sh
(B) Humanities (including Forelgn Language, Fine Arts, Music, Philosophy, Religion, Art)
(C) Mathemat1cs
(D) Phystcal and Blological Sciences
(E) History and Social Sciences

24. In comparison with fellow students in classes at your college, which of the following best describes your academic performance so far in college.
(A) In the top quarter
(B) In the second quarter
(C) In the third quarter
(D) In the lowest quarter

25. How well has your academic performance in college compared with your expectations?
(A) I have done better than I expected to do.
(B) I have done about as well as I expected to do.
(C) I have not done as well as I expected to do. 
100

Appendix C

Directions for the Essay Test 
101

Directions for the Essay Test

Introduction: The English Composition Essay Test consists of two sections. Section One is 30 minutes, and Section Two is 60 minutes. Record your essays on the lined paper we have provided. Make sure that your name is at the top of the first page.

You may proceed from one section of the test to the next without waiting for a signal from me. However, when 30 minutes have elapsed, I will announce that even though you may not have finished Section One, you must proceed to Section Two. Are there any questions?

SECTION I

When I give the signal, open your test booklet to Section One, read the directions, and begin work. You will have 30 minutes to work on Section One. Begin work.

SECTION II

(At the end of 30 minutes) If you have not already done 80 , begin work on Section Two which consists of Parts A,B, and C. You, will have 60 minutes to work on Section Two. If you finish your work on Section Two before time is called, you may turn back and work on Section One. 
102

Appendix D

Multiple Regression Data 
Name and Number of Each Variable as it is Listed in the Multiple Regression Anslysis

$\begin{array}{ll}\text { No. } & \frac{\text { Name }}{1} \\ 2 & \text { Essay Test Score } \\ 3 & \text { ACT Engliah Score } \\ 4 & \text { ACT Mathematics Score } \\ 5 & \text { ACT Social Studies Score } \\ 6 & \text { ACT Natural Science Score } \\ & \text { ACT Composite Score }\end{array}$

$\frac{\text { Yo. }}{7}$
8
9
10
11
12

Name

High School English Grade High School Mathematics Grade High School Social Studies Grade High School Natural Science Grade Objective Test Score Freshmen English GPA

Multiple Regression Data

REGRESSION ANALYSIS OF VARIABLE 12 (Freshmen English GPA--Dependent Variable)

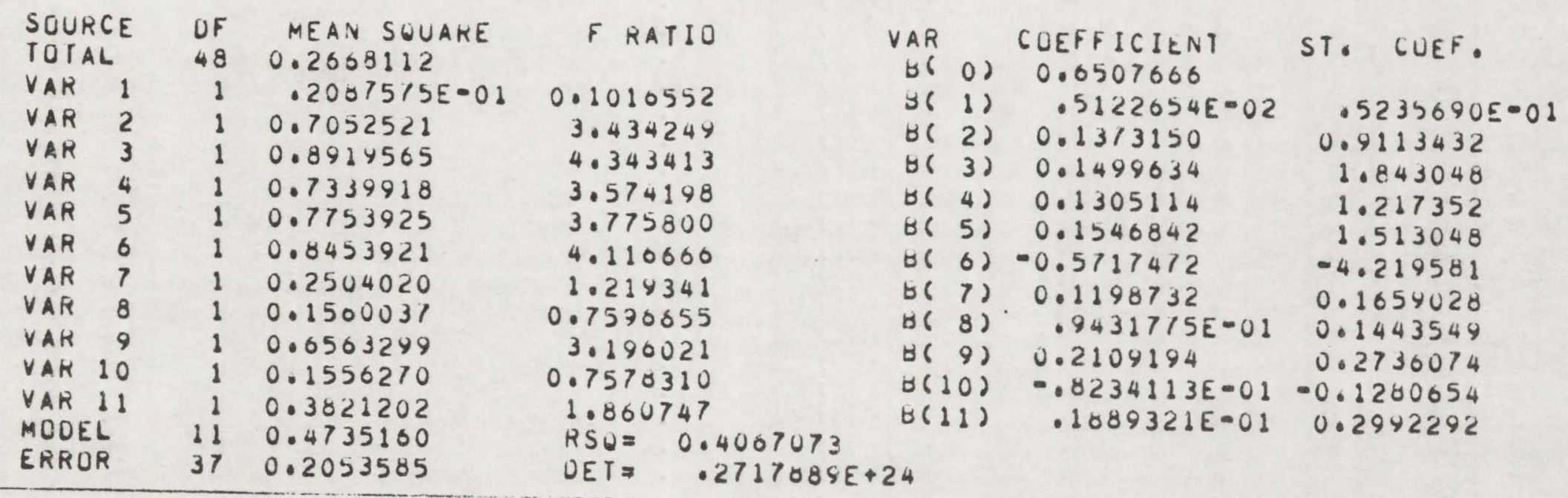

AVE

2.583573

12.40816

19.55102

$18.6 \times 388$

20.40980

21.82633

20.20531

3.224490

2.714286

3.265306

$2.97 \times 592$

44.10204 
Regression Data Continued (2)

VARIABLE 1 WILL NOW BE DELETED (Essay Test Score)

REGRESSION ANALYSIS UF VAKIABLE 12

\begin{tabular}{|c|c|c|c|c|c|c|}
\hline SOURCE & $\Delta F$ & MEAN SUUARE & F RATIO & VAR & COEFF ICIENT & COEF. \\
\hline TOTAL & 48 & 0.2608112 & & $\forall\left(\begin{array}{ll}0 & 0\end{array}\right)$ & 0.6169003 & \\
\hline VAR I: & 1 & 0.4947511 & $2.46 / 542$ & $\forall(11)$ & $.2032938 E=01$ & 0.3219752 \\
\hline VAR & 1 & 0.7309237 & 3.075363 & $\forall(2)$ & 0.1396670 & 0.3209535 \\
\hline VAR & 1 & 0.8979156 & 4.470300 & $86(3)$ & 0.1204321 & 1.848008 \\
\hline VAR & 1 & 0.7296291 & 3.630982 & $B(4)$ & 0.1301003 & 1.213517 \\
\hline VAK & l & $0.78<2608$ & 3.901479 & $B(5)$ & 0.1553191 & 1.519259 \\
\hline YAR & 1 & 0.8528401 & 4.253529 & $8(6)$ & $=0.5740709$ & -4.236730 \\
\hline$\checkmark A R$ & 1 & 0.2633798 & 1.313591 & $B(7)$ & 0.1225673 & 0.1646314 \\
\hline VAR & 1 & 0.1836383 & 0.9150850 & $\forall(8)$ & 0.1006132. & 0.1539901 \\
\hline VAR & 1 & 0.6400569 & 3.192246 & $8(9)$ & 0.2073406 & 0.2689727 \\
\hline VAR IC & 1 & 0.1478707 & 0.7374962 & $8(10)$ & $\because .8002617 E=01$ & -0.124465 \\
\hline MODEL & 10 & 0.5187800 & $R S_{Q}=$ & & & \\
\hline ERROR & 38 & 0.2005036 & DE $T=$ & 21 & & \\
\hline
\end{tabular}

VARIAELE 10 WILL NUW OE DELETED (Bigh School Natural Science Grade)

REGRESSION ANALYSIS UF VARIABLE 12

\begin{tabular}{|c|c|c|c|c|c|c|c|}
\hline $\begin{array}{l}\text { SOURCE } \\
\text { TUTAL }\end{array}$ & $\begin{array}{l}\text { DF } \\
48\end{array}$ & $\begin{array}{l}\text { MEAIN SQUARE } \\
0.2608122\end{array}$ & F RATIO & $\begin{array}{l}\text { VAR } \\
\text { OS }\end{array}$ & $\begin{array}{c}\text { COEFFICIENT } \\
0.5284247\end{array}$ & ST, COEF. & $\begin{array}{c}\text { AVE } \\
2.585673\end{array}$ \\
\hline VAR 1 & 1 & 0.6020052 & 3.022811 & $B(d+1)$ & $.2212899 E=01$ & 0.3504772 & 44.10204 \\
\hline VAR & 1 & 0.0002401 & 3.054118 & $\forall 62)$ & 0.1212915 & 0.8049974 & 19.50102 \\
\hline VAR & 1 & 0.7882883 & 3.958183 & $B(3)$ & 0.1379929 & 1.695931 & 18.64388 \\
\hline VAR & 1 & 0.6163992 & 3.093087 & $B(4)$ & 0.1161267 & 1.083178 & 20.40980 \\
\hline $\begin{array}{l}\text { VAR } \\
\text { VAK }\end{array}$ & 1 & $\begin{array}{l}0.6627429 \\
0.7303108\end{array}$ & $\begin{array}{l}3.321789 \\
3.097191\end{array}$ & of 5$)$ & $\begin{array}{r}0.1304036 \\
-0.5171273\end{array}$ & 1.353818 & $\begin{array}{l}21.81033 \\
20.20531\end{array}$ \\
\hline VAK & $\begin{array}{l}1 \\
1\end{array}$ & 0.2336163 & $\begin{array}{l}3.677191 \\
1.173043\end{array}$ & $\begin{array}{l}8\left(\begin{array}{l}3 \\
6(\end{array}\right) \\
6(7)\end{array}$ & $\begin{array}{r}-0.5171273 \\
0.1150407\end{array}$ & $\begin{array}{l}-3.831239 \\
0.1592229\end{array}$ & $3.224490=$ \\
\hline VAK & 1 & 0.1089594 & 0.5471111 & $b(8)$ & $.7407779 E-01$ & 0.1133773 & 2.714286 \\
\hline VAR S & 1 & 0.6411842 & 3.219538 & $B(9)$ & 0.2075208 & 0.2692090 & 3.265306 \\
\hline MOOEL & 9 & 0.5599922 & $R S Q=$ & & & & \\
\hline ERROR & 39 & 0.1991541 & .147905 & & & & \\
\hline
\end{tabular}


Regression Data Continued (3)

VARIABLE 8 WILL NOW BE DELETEO (High School Mathematics Grade)

REGRESSION ANALYSIS OF VARIABLE 12

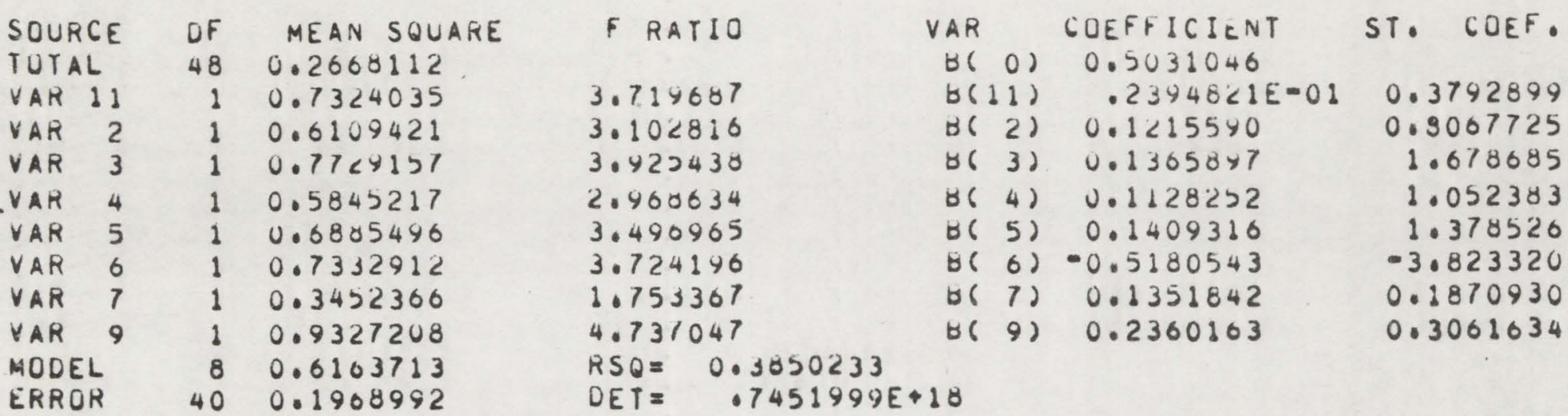

VARIABLE 7 WILL NOW $U E$ OELETED (HIgh School anglish Grade)

REGRESSION ANALYSIS UF VARIABLE 12

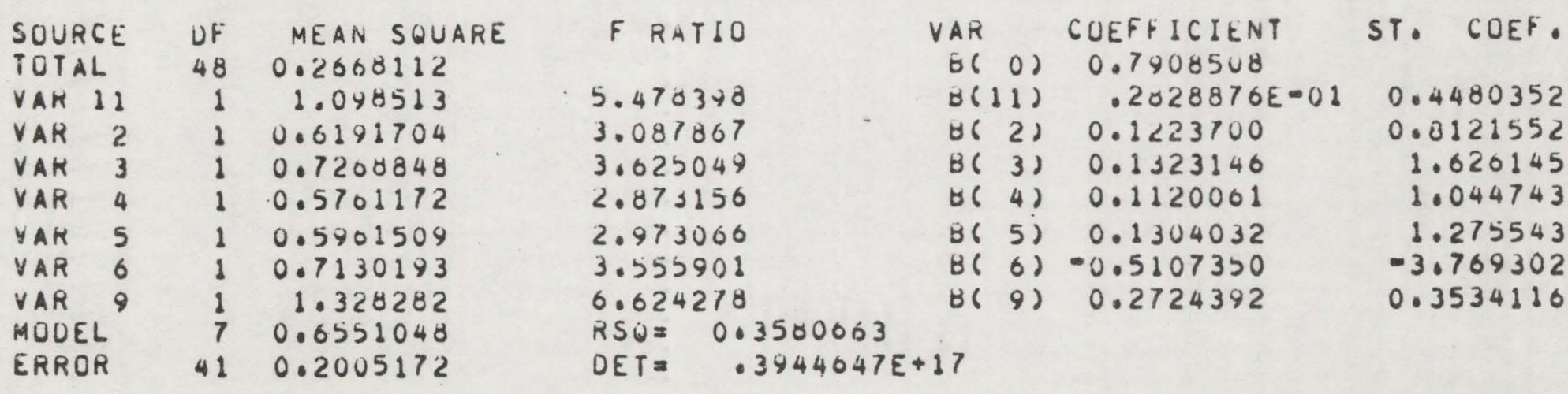

A V t

2.585673 $44.1 \cup 204$ 19.52102 18.69388 20.40980 21.81633 20.20531 3.265306 
Regression Data Continued (4)

VARIABLE 4 WILL NOW $8 E$ OLLETED (ACT Social Studies Score)

REGRESSION ANALYSIS UF VARIABLE 12

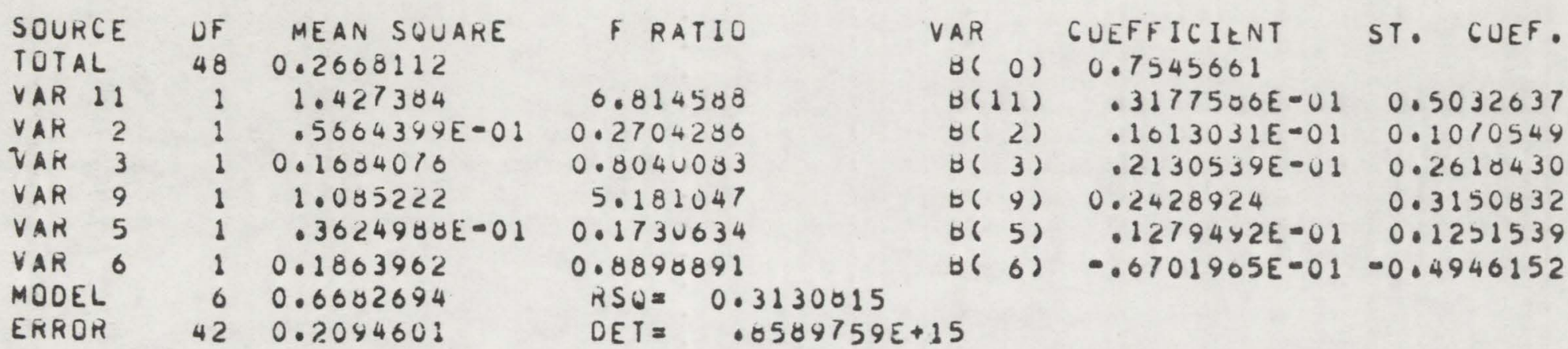

AVE 2.583673 44.10204 19.52102 . $8.6 \times 388$ 3.202300 21.81033 20.20531

VARIABLE S WILL NOW BE DELETED (ACT Natural Science Score)

REGRESSION ANALYSIS OF VARIABLE 12

\begin{tabular}{|c|c|c|c|c|c|c|}
\hline $\begin{array}{l}\text { SOURCE } \\
\text { TOTAL }\end{array}$ & $\begin{array}{l}\text { DF } \\
48\end{array}$ & $\begin{array}{l}\text { MEAIN SQUARE } \\
0.2608112\end{array}$ & F RATIO & $\begin{array}{l}\text { VAR } \\
\text { B( }(0)\end{array}$ & $\begin{array}{c}\text { COEFFICILNT } \\
0.7321523\end{array}$ & COEF. \\
\hline VAR I1 & 1 & 1.722522 & 0.384879 & $B(11)$ & $.33296 \angle 5 E-01$ & 0.5273434 \\
\hline VAK 2 & 1 & $.31825895-01$ & 0.1549218 & $8(2)$ & $.1115657 E-U 1$ & $.7404485 E-01$ \\
\hline VAR & 1 & 0.1333237 & $0.648 \times 924$ & $\forall(3)$ & $.1002414 E-01$ & 0.1909364 \\
\hline VAR & 1 & 1.001076 & 5.165097 & $8(9)$. & 0.2302840 & 0.2987273 \\
\hline VAR & 1 & 0.1924887 & 0.9369953 & $B(6)$ & $-.4473347 E-01$ & -0.3301399 \\
\hline MODEL & 5 & 0.7946733 & 0.3102511 & & & \\
\hline ERROR & 43 & 0.2054319 & .3879268 & 13 & & \\
\hline
\end{tabular}

$A V E$

2.581673 44.10204 19.55102 18.64388 3.265306 20.26531 
Regression Data Cortinued (5)

VARIABLE 2 WILL NOW BE DELETEO (ACT English Sicore)

REGRESSIOIN ANALYSIS OF VARIABLE 12

\begin{tabular}{|c|c|c|c|c|c|c|}
\hline SOURCE & DF & MEAIV SWUARE & F RATIU & VAR & COEFHICIENT & COEF. \\
\hline TOTAL & 48 & 0.2608112 & & $B\left(\begin{array}{ll}( & 0\end{array}\right)$ & $0.8<75145$ & \\
\hline VAR II & 1 & 1.755609 & 8.713690 & $8(11)$ & $.3355871 E-U 1$ & 0.5315002 \\
\hline VAR & 1 & 0.1605101 & 0.8363651 & $8(6)$ & $-3432432 E=01$ & -0.2533187 \\
\hline VAR & 1 & 0.1035801 & $0.51407 y 9$ & $86(3)$ & $.1310694 E-01$ & 0.1610842 \\
\hline VAR 9 & 1 & 1.029713 & 5.110585 & $86(9)$ & $0.2<25594$ & 0.28870 \\
\hline $\begin{array}{l}\text { MODEL } \\
\text { ERROR }\end{array}$ & $\begin{array}{r}4 \\
44\end{array}$ & $\begin{array}{l}0.9853851 \\
0.2014863\end{array}$ & $\begin{array}{ll}\text { RSQ } & =0.3077060 \\
\text { DET }= & .1517158\end{array}$ & & & \\
\hline
\end{tabular}

VARIABLE 3 WILL NOW BE DELETEO (ACT Mathematics Score)

REGRESSION ANALYSIS OF VARIABLE 12

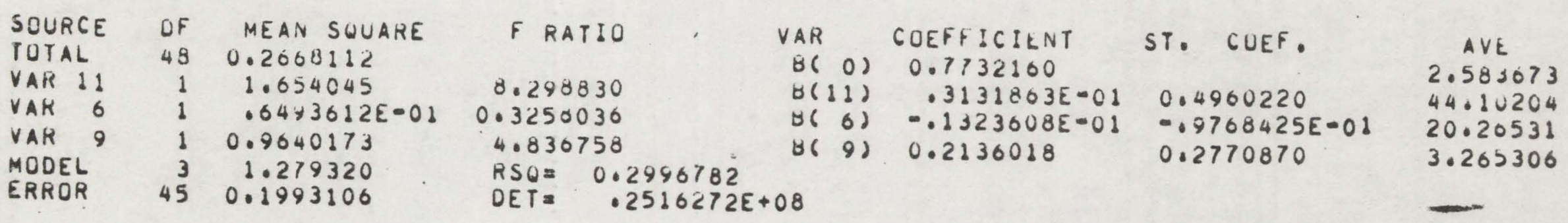


Regresaion Data Continued (6)

VARIABLE 6 WILL NOW BE DELETED (ACT Composite Score)

REGRESSION ANALYSIS OF VARIABLE 12

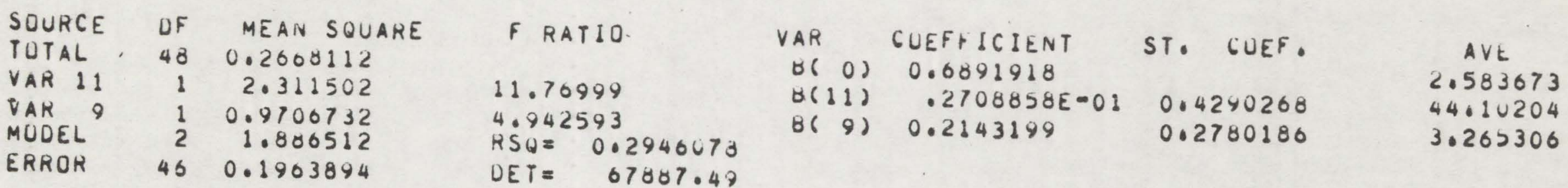

VARIABLE 9 WILL INOW BE OELETED (High School Social Studies Grade)

REGRESSION ANALYSIS OF VARIABLE 12

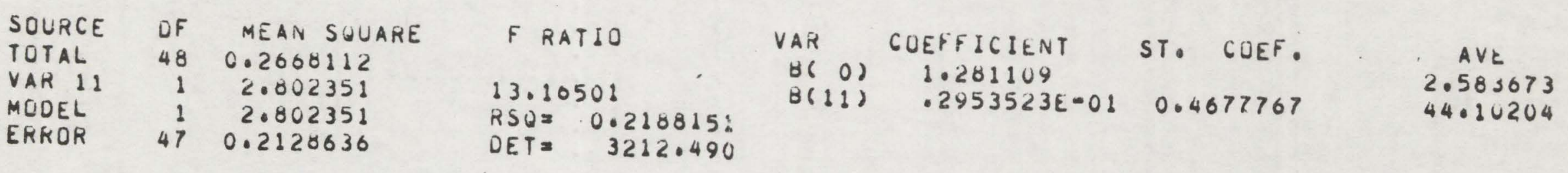

VARIABLE 11 (Objective Test Score) 
VITA

Mark Guymon Christensen

Candidate for the Degree of

Doctor of Philosophy

Dissertation: The Validity of Awarding Credit by Examination in English Composition

Major Field: Educational Psychology

Biographical Information:

Personal Data: Born at Huntington, Utah, April 10, 1945, son of Paul D. and Beth Guymon Christensen; married Janet Jean Jensen, June 9, 1972.

Education: Attended elementary school in Ysleta, Texas, and Logan, Utah; graduated from Logan High School in 1963; received the Bachelor of Science degree from Utah State University, with a major in political science, in 1969; received the Master of Science degree at Utah State University in 1971; completed requirements for the Doctor of Philosophy degree at Utah State University in 1973.

Professional Experience: 1970-73, research assistant, Utah State University Counseling and Testing Center; 1969-70, counselor, Logan Junior High School; 1966-70, clerical assistant, Utah State University Extension Service. 